\title{
Equilibrium and Fractional Crystallization Experiments at 0.7 GPa; the Effect of Pressure on Phase Relations and Liquid Compositions of Tholeiitic Magmas
}

\section{SAMUEL VILLIGER ${ }^{1}$, PETER ULMER $^{1 *}$ AND OTHMAR MÜNTENER $^{2}$}

${ }^{1}$ DEPARTMENT OF EARTH SGIENCES, ETH ZÜRICH, SONNEGGSTRASSE 5, CH-8092 ZÜRICH, SWITZERLAND

${ }^{2}$ INSTITUTE OF GEOLOGICAL SGIENGES, UNIVERSITY OF BERN, BALTZERSTRASSE 1, CH-3012 BERN, SWITZERLAND

\section{RECEIVED FEBRUARY 21, 2006; ACGEPTED AUGUST 11, 2006; ADVANGE ACGESS PUBLICATION OCTOBER 31, 2006}

Two series of anhydrous experiments have been performed in an end-loaded piston cylinder apparatus on a primitive, mantle-derived tholeiitic basalt at $0.7 \mathrm{GPa}$ pressure and temperatures in the range $1060-1270^{\circ} \mathrm{C}$. The first series are equilibrium crystallization experiments on a single basaltic bulk composition; the second series are fractionation experiments where near-perfect fractional crystallization was approached in a stepwise manner using $30^{\circ} \mathrm{C}$ temperature increments and starting compositions corresponding to that of the previous, higher temperature glass. At $0.7 \mathrm{GPa}$ liquidus temperatures are lowered and the stability of olivine and plagioclase is enhanced with respect to clinopyroxene compared with phase equilibria of the same composition at 1.0 GPa. The residual solid assemblages of fractional crystallization experiments at $0.7 \mathrm{GPa}$ evolve from dunites, followed by wehrlites, gabbronorites, and gabbros, to diorites and ilmenite-bearing diorites. In equilibrium crystallization experiments at 0.7 GPa dunites are followed by plagioclase-bearing websterites and gabbronorites. In contrast to low-pressure fractionation of tholeiitic liquids (1 bar-0.5 GPa), where early plagioclase saturation leads to the production of troctolites followed by (olivine) gabbros at an early stage of differentiation, pyroxene still crystallizes before or with plagioclase at $0.7 \mathrm{GPa}$. The liquids formed by fractional crystallization at $0.7 \mathrm{GPa}$ evolve through limited silica increase with rather strong iron enrichment following the typical tholeiitic differentiation path from basalts to ferro-basalts. Silica enrichment and a decrease in absolute iron and titanium concentrations are observed in the last fractionation step after ilmenite starts to crystallize, resulting in the production of an andesitic liquid. Liquids generated by equilibrium crystallization experiments at $0.7 \mathrm{GPa}$ evolve through constant $\mathrm{SiO}_{2}$ increase

*Corresponding author. Telephone: +41-1-632-3955. Fax: +41-1-6321088. E-mail: peter.ulmer@erdw.ethz.ch and only limited $\mathrm{Fe} O$ enrichment as a consequence of spinel crystallization and closed-system behaviour. Empirical calculations of the (dry) liquid densities along the liquid lines of descent at 0.7 and 1.0 GPa reveal that only differentiation at the base of the crust (1.0 GPa) results in liquids that can ascend through the crust and that will ultimately form granitoid plutonic and/or dacitic to rhyodacitic sub-volcanic to volcanic complexes; at 0.7GPa the liquid density increases with increasing differentiation as a result of pronounced $\mathrm{Fe}$ enrichment, rendering it rather unlikely that such differentiated melt will reach shallow crustal levels.

KEY WORDS: tholeiitic magmas; experimental petrology; equilibrium crystallization; fractional crystallization

\section{INTRODUGTION}

Numerous processes have been identified that modify the compositions of mantle-derived basaltic magmas at different depths during their ascent from the source region towards the surface. In addition to assimilation of country rocks, trapping of interstitial liquids in cumulates, mixing of different magma types and replenishment of magma chambers with less differentiated magmas, crystal fractionation is generally identified as the predominant process operating in crustal magma reservoirs.

Petrological, geochemical (including isotope geochemistry) and experimental studies on continental and oceanic flood basalts (Cox, 1980; Thompson et al., 1980;

(C) The Author 2006. Published by Oxford University Press. All rights reserved. For Permissions, please email: journals.permissions@ oxfordjournals.org 


\section{\begin{tabular}{l|l|l|l} 
JOURNAL OF PETROLOGY & VOLUME 48 & NUMBER 1 & JANUARY 2007
\end{tabular}}

Lightfoot et al., 1990) clearly support the view that crystal fractionation is the predominant process involved in the evolution of continental basalts once they cross the crust-mantle boundary. Underplating of large volumes of mafic magma at the base of the thinned continental crust during rifting is suggested by geophysical studies of rifted continental margins (Mutter et al., 1984; Holbrook \& Kelemen, 1993). Exposed sections of lower crustal rocks in the Alps such as the Malenco (Müntener et al., 2000; Hermann et al., 2001) or the Ivrea-Verbano Zone (Rivalenti et al., 1975, 1984) reveal the presence of massive amounts of ultramafic to mafic cumulates of tholeiitic affinity. These cumulate rocks have been explained by igneous underplating at the crust-mantle boundary (e.g. Bergantz, 1989) and intrusion of the continental crust by basaltic magmas equilibrated at depths between

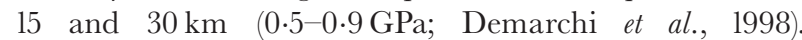
These magmas are also thought to be responsible for the occurrence of widespread silicic magmatism that is temporally and spatially associated with the mafic intrusive rocks either as direct products of the crystallization of these magmas and/or by partial fusion of lower crustal lithologies by the heat provided by these magmas.

Experimental determinations of the olivine- ${ }^{-} \mathrm{px}^{-}$ plagioclase saturation surfaces of anhydrous basalts by Grove and coworkers (Tormey et al., 1987; Bartels et al., 1991; Grove et al., 1992; Kinzler \& Grove, 1992; Yang et al., 1996) led to quantitative models over a range of pressures, temperatures and compositions. Estimated crystallization pressures on the basis of cpx-saturated liquids from a large dataset of mid-ocean ridge glasses (Michael \& Cornell, 1998; Herzberg, 2004; Villiger et al., 2006) show that mid-ocean ridge basalts crystallize at variable depths beneath spreading centres, both in the oceanic crust and within the underlying mantle, at depths to $30 \mathrm{~km}$. The highest crystallization pressures are obtained for basaltic glasses extruded at ultra-slow spreading ridges, particularly along fracture zones.

The majority of experiments on anhydrous basaltic liquids at elevated pressures (Bender et al., 1978; Baker \& Eggler, 1983, 1987; Grove \& Bryan, 1983; Elthon \& Scarfe, 1984; Gust \& Perfit, 1987; Grove et al., 1990, 1992; Bartels et al., 1991; Fram \& Longhi, 1992; Kinzler \& Grove, 1992) have been designed to establish near-liquidus phase relations (multiple-saturation experiments). These experiments generally do not cover the entire temperature and composition range of magmatic differentiation. In addition, some of these studies were performed with starting compositions that are not consistent with a primary mantle origin, i.e. using bulk compositions with $\mathrm{Mg}$-number [molar $\mathrm{Mg} /\left(\mathrm{Mg}+\mathrm{Fe}_{\text {tot }}\right)$ ] considerably below 0.70, values inconsistent with equilibration with mantle peridotite (Roedder \& Emslie, 1970; Ulmer, 1989).

Cumulate rocks with textures varying from adcumulates to orthocumulates are the product of solid-liquid separation processes, most obviously demonstrated by cumulate rocks exhibiting modal and grain-size layering. They imply fractional crystallization in a dynamic magma system as the predominant differentiation process. Applying equilibrium crystallization or partial melting experiments performed on a constant bulk composition cannot simulate this process accurately. The experimental liquid lines of descent result in different phase relations and liquid compositions for fractional crystallization and for equilibrium crystallization experiments in a natural multi-component system at 1.0 GPa (Villiger et al., 2004). Attempts to reproduce experimental liquid lines of descent with currently available thermodynamic models (e.g. MELTS and pMELTS, Ghiorso \& Sack, 1995; Asimow \& Ghiorso, 1998; Ghiorso et al., 2002) result in liquid compositions and phase relations that are significantly different from our previous experimental results at 1.0 GPa (Villiger et al., 2004).

In summary, field, petrological and geochemical studies on crustal rocks of tholeiitic affinity unambiguously underline the importance of crystal-liquid differentiation processes operating at pressures corresponding to conditions at the base of the continental crust or within the mantle below mid-ocean ridges.

To explore the effects of pressure on the two crystallization processes, we performed two series of piston cylinder experiments at $0.7 \mathrm{GPa}$ : fractional and equilibrium crystallization. We present quantitative data on the phase relations, phase proportions, the compositions of melts and coexisting crystalline products as well as mineralliquid partitioning, derived from both fractional and equilibrium crystallization experiments. To resolve the effect of crystallization pressure on the differentiation of tholeiitic magmas, the data are compared with our previous fractional and equilibrium crystallization experiments at $1.0 \mathrm{GPa}$ using the same starting materials (Villiger et al., 2004) and equilibrium crystallization experiments conducted between 1 bar and 1.0 GPa on different natural starting compositions (Bender et al., 1978; Baker \& Eggler, 1983, 1987; Grove \& Bryan, 1983; Elthon \& Scarfe, 1984; Gust \& Perfit, 1987; Tormey et al., 1987; Grove et al., 1990, 1992; Bartels et al., 1991; Fram \& Longhi, 1992; Kinzler \& Grove, 1992; Yang et al., 1996; Sano et al., 2001; P. Ulmer, unpublished data). Calculated densities for the liquids in the fractional and equilibrium crystallization experiments and their consequences for ascent of primitive and differentiated magmas from lower crustal magma reservoirs are presented and discussed.

\section{EXPERIMENTAL TEGHNIQUES Experimental strategy}

Two contrasting experimental series were performed at $0.7 \mathrm{GPa}$, subsequently referred to as equilibrium and fractional crystallization experiments, respectively. 
For the equilibrium crystallization experiments a single starting composition (a primitive tholeiitic basalt) was used. Temperature was lowered by $30^{\circ} \mathrm{C}$ for successive runs. An approximation to pure fractional crystallization was achieved by a stepwise approach. In each experiment the liquid compositions were determined. The succeeding experiment was then performed at a $30^{\circ} \mathrm{C}$ lower temperature starting with a synthetic mixture that corresponds to the liquid composition from the previous (higher temperature) experiment. This approach used to simulate fractional crystallization (by removal of all solid phases) has successfully been applied by Villiger et al. (2004) for anhydrous tholeiitic liquids at 1.0 GPa and for fractionation of a hydrous picrobasalt and a high- $\mathrm{Mg}$ basaltic andesite by Kägi (2000). This experimental strategy results in variable but relatively high melt fractions (from 0.94 to $0 \cdot 40$ ) that allow us to perform experiments over a large range of differentiation with the possibility of obtaining precise liquid compositions. Based on temperature reproducibility in piston cylinder experiments $\left( \pm 15^{\circ} \mathrm{C}\right)$, temperature increments of $30^{\circ} \mathrm{C}$ were chosen for successive experiments. Smooth variations of phase relations and liquid compositions are taken as an indication that we did not seriously overstep any important peritectic reaction that might significantly alter the overall liquid line of descent.

\section{Starting materials}

The starting compositions used for the anhydrous experiments at $0.7 \mathrm{GPa}$ are listed in Table 1. Composition HK\#19 represents a primitive basaltic glass composition
(Mg-number 0.76) derived through dry partial melting experiments by Hirose \& Kushiro (1993) on KLB1 peridotite composition. This composition is in equilibrium with a lherzolitic residue (ol, opx, cpx) at $1.5 \mathrm{GPa}$ and $1350^{\circ} \mathrm{C}$. To compare the experimental results at $0.7 \mathrm{GPa}$ with the previous experiments at $1.0 \mathrm{GPa}$ (Villiger et al., 2004), the same initial starting composition was used. Equilibrium crystallization experiments were performed with composition HK\#19.1 (HK\#19+0.5 wt \% pure anorthite seeds added to prevent overstepping of the plagioclase liquidus as a result of retarded nucleation); fractional crystallization experiments started with HK\#19.2, which contained 0.5 wt $\%$ natural forsterite $\left(\mathrm{F}_{90}\right)$ in addition to anorthite used to guarantee olivine saturation at the liquidus at $1 \mathrm{GPa}$ (Villiger et al., 2004). Starting materials 7Fr1 to 7Fr7 correspond to the average glass compositions of the previous, higher temperature experiment (Tables 1 and 3) renormalized to $100 \%$ oxide total. Starting materials were synthesized from chemicals for each subsequent fractional crystallization experiment. The choice of slightly different initial starting compositions used for fractional and equilibrium crystallization experiments has been discussed by Villiger et al. (2004).

The starting materials consist of mixes of fired synthetic and natural oxides, silicates and carbonates. A mixture of finely ground refractory components $\left(\mathrm{SiO}_{2}, \mathrm{TiO}_{2}\right.$, $\left.\mathrm{Al}_{2} \mathrm{O}_{3}, \mathrm{CaAl}_{2} \mathrm{Si}_{2} \mathrm{O}_{8}, \mathrm{CaCO}_{3}, \mathrm{MgO}, \mathrm{Cr}_{2} \mathrm{O}_{3}\right)$ was fired for $2 \mathrm{~h}$ at $1100^{\circ} \mathrm{G}$ to completely dehydrate the oxides and decarbonize the $\mathrm{CaCO}_{3}$. This mixture was added to the finely ground reactive components $\left(\mathrm{Fe}_{2} \mathrm{SiO}_{4}, \mathrm{MnO}\right.$,

Table 1: Starting compositions

\begin{tabular}{|c|c|c|c|c|c|c|c|c|c|c|c|}
\hline Sample & $\mathrm{SiO}_{2}$ & $\mathrm{TiO}_{2}$ & $\mathrm{Al}_{2} \mathrm{O}_{3}$ & $\mathrm{Cr}_{2} \mathrm{O}_{3}$ & $\mathrm{FeO}_{\text {tot }}$ & $\mathrm{MnO}$ & $\mathrm{MgO}$ & $\mathrm{CaO}$ & $\mathrm{Na}_{2} \mathrm{O}$ & $\mathrm{K}_{2} \mathrm{O}$ & Mg-no. \\
\hline HK\#19 & $49 \cdot 10$ & 0.60 & $15 \cdot 17$ & 0.36 & 7.54 & 0.14 & $13 \cdot 10$ & $12 \cdot 27$ & 1.58 & 0.08 & 0.76 \\
\hline НК\#19.1 & $49 \cdot 07$ & 0.60 & $15 \cdot 28$ & 0.36 & 7.50 & 0.14 & $13 \cdot 04$ & $12 \cdot 31$ & 1.57 & 0.08 & 0.76 \\
\hline HK\#19.2 & 48.67 & 0.57 & 14.55 & 0.34 & 7.56 & 0.14 & 14.81 & 11.73 & 1.50 & 0.08 & 0.78 \\
\hline 7Fr1 & $50 \cdot 24$ & 0.59 & 14.59 & 0.31 & $7 \cdot 36^{*}$ & $0 \cdot 16$ & 12.85 & $12 \cdot 17$ & 1.65 & 0.09 & 0.76 \\
\hline $7 F r 2$ & 51.55 & 0.61 & 14.99 & 0.19 & $7 \cdot 35$ & 0.13 & $10 \cdot 78$ & $12 \cdot 32$ & 1.96 & 0.14 & 0.72 \\
\hline 7Fr3 & 52.01 & 0.74 & $16 \cdot 22$ & 0.05 & $8 \cdot 11$ & 0.14 & $8 \cdot 05$ & 11.91 & 2.55 & 0.22 & 0.64 \\
\hline $7 F r 4$ & $52 \cdot 25$ & 0.95 & 15.95 & 0.02 & 9.90 & 0.16 & 7.22 & $10 \cdot 32$ & 2.92 & 0.31 & 0.57 \\
\hline $7 F r 5$ & $53 \cdot 38$ & 1.79 & 14.99 & 0.02 & 12.53 & 0.20 & $4 \cdot 38$ & 8.43 & 3.52 & 0.75 & 0.38 \\
\hline 7Fr6 & 53.88 & 2.58 & 13.82 & 0.02 & 14.62 & 0.23 & 2.94 & 7.00 & 3.65 & 1.26 & 0.26 \\
\hline 7Fr7 & 54.25 & $3 \cdot 10$ & 12.74 & 0.03 & 16.65 & 0.21 & 1.80 & 5.91 & 3.40 & 1.91 & 0.16 \\
\hline
\end{tabular}

The starting material HK\#19 used in equilibrium crystallization experiments represents a basaltic liquid in equilibrium with a Iherzolitic residuum at $1.5 \mathrm{GPa}$ and $1350^{\circ} \mathrm{C}$ (Hirose \& Kushiro, 1993). HK\#19.1 is HK\#19+0.5 wt\% pure anorthite seeds. For the fractional crystallization experiment SV76 HK\#19.2 [HK\#19+0.5 wt\% anorthite seeds +5.0 wt $\%$ natural forsterite $\left(\mathrm{Fo}_{90}\right)$ ] was used. Starting materials 7Fr1 and 7Fr7 correspond to the glass compositions of the previous, $30^{\circ} \mathrm{C}$ higher temperature, experiment (see Tables 2 and 3). $\mathrm{FeO}_{\text {tot }}$ and $\mathrm{Mg}$-number: all $\mathrm{Fe}$ as $\mathrm{Fe}^{2+}$. Uncertainties from weighing are $<0.1 \%$ relative for the major elements and $<1 \%$ relative for the minor elements $\left(\mathrm{Cr}_{2} \mathrm{O}_{3}, \mathrm{MnO}, \mathrm{K}_{2} \mathrm{O}\right)$.

${ }^{*} \mathrm{FeO}_{\text {tot }}$ was corrected for experiments with $\Delta \mathrm{Fe}>2.0 \mathrm{wt} \%$ (see Table 2). 
$\mathrm{Na}_{2} \mathrm{SiO}_{3}, \mathrm{KAlSi}_{3} \mathrm{O}_{8}$, ) in weight proportions appropriate to obtain $2.5 \mathrm{~g}$ of starting material. The final powders were homogenized by regrinding in an agate mill for $1 / 2 \mathrm{~h}$ under ethanol and dried for at least 1 day at $220^{\circ} \mathrm{C}$.

\section{Experimental set-up}

To minimize Fe loss to the noble metal capsule and to constrain the $f \mathrm{O}_{2}$ near the $\mathrm{C}-\mathrm{CO}_{2}-\mathrm{CO}$ equilibrium, the $\mathrm{Pt}$-graphite double capsule technique was applied (Ulmer \& Luth, 1991). A graphite container was filled with the powdered starting material and closed with a tight-fitting lid $(2.6 \mathrm{~mm}$ outer diameter; $1.5 \mathrm{~mm}$ inner diameter). The graphite container was placed in a 3. $0 \mathrm{~mm}$ Pt-capsule and welded shut.

All nominally anhydrous experiments were performed in solid media high-pressure apparatus at the ETH Zürich. An end-loaded piston cylinder apparatus (Boyd \& England, 1960) with a 14 mm bore was used. NaCl-Pyrex$\mathrm{MgO}$ assemblies with a friction correction of $-3 \%$ applied to the nominal pressure were used to the highest temperatures. Pressure was calibrated against the univariant reaction fayalite + quartz $=$ orthoferrosilite at $1000^{\circ} \mathrm{C}$ and $141 \mathrm{GPa}$ (Bohlen et al., 1980) and the quartz-coesite transition at $1000^{\circ} \mathrm{C}$ and $3.07 \mathrm{GPa}$ (Bose \& Ganguly, 1995). This experimental study was conducted in the lower pressure range feasible for piston cylinder apparatus and, therefore, pressure accuracy and reproducibility are important issues because we compare $0.7 \mathrm{GPa}$ experiments (this study) with $1.0 \mathrm{GPa}$ experiments reported by Villiger et al. (2004). The assembly employed $[\mathrm{NaCl}$ outer sleeve shielded by Pyrex glass from the graphite furnace and high-porosity $(>10 \%) \mathrm{MgO}$ as internal parts] was tested for 'low' pressure performance by measuring the $\mathrm{LiCl}$ and $\mathrm{CsCl}$ melting curves that have accurately been determined by Clark (1959) as a function of pressure and temperature. We used a 'pressure analysis technique' to determine the melting point of $\mathrm{LiCl}$ in situ as described by Brey et al. (1990) for silver melting in a belt apparatus in the range $0.5-0.8 \mathrm{GPa}$. Absolute precision and accuracy were about $0.05 \mathrm{GPa}$. Temperatures were measured with $\mathrm{Pt}_{94} \mathrm{Rh}_{6}-\mathrm{Pt}_{70} \mathrm{Rh}_{30}$ (B-type) thermocouples with an estimated accuracy of $\pm 10^{\circ} \mathrm{C}$, without taking into account the effect of pressure on the e.m.f. To assess potential 'thermocouple poisoning' of the $\mathrm{Pt}-\mathrm{Rh}$ thermocouples we continuously monitored the output-power of the thyristor unit, which resulted in a nearly constant power demand over the duration of the experiment after an initial power increase attributed to thermal equilibration and mechanical relaxation of the assembly.

\section{Analytical methods}

All experimental run products were analysed using five spectrometer electron microprobes (Cameca SX50 and Jeol 8200) at the Institute for Mineralogy and Petrology,
ETH Zürich. A $15 \mathrm{kV}$ accelerating potential, $7 \mathrm{nA}$ beam current and $10 \mu \mathrm{m}$ beam size were used for analyses of the quenched glasses. The crystalline phases were analysed with a $20 \mathrm{nA}$ beam current and $1 \mu \mathrm{m}$ beam size. All elements were analysed for $20 \mathrm{~s}$, except for $\mathrm{Na}$ in quenched glasses, for which the counting time was $10 \mathrm{~s}$ to minimize potential Na loss. Depending on the quality of the polished surface of the experimental charges all glass analyses summed to between 96.4 and 99.6 wt \% (Table 3). For graphic representation, calculation of modal proportions and internal consistency with previous experiments (Villiger et al., 2004), glass analyses have been normalized to $100 \mathrm{wt} \%$. The same set of standards and identical data reduction schemes (ZAF) were used for both microprobes; results are, within statistical error, indistinguishable between the two electron probe microanalysers employed in this work.

Modal proportions of phases in the high-pressure run products reported in Table 2 were estimated using nonweighted least-squares regression analyses balancing the nominal composition of the bulk starting material against the averages of all analysed phases in the experimental charges. Errors indicated in Table 2 are the statistical errors calculated by the least-squares regression routine implemented in the EXCEL spreadsheet program. Table 2 reports the sum of the residuals squared $\left(\Sigma r^{2}\right)$, which is less than $0 \cdot 36$, except for SV76 (0.69). If calculated Fe loss (see Table 2 and discussion below) exceeded $2 \%$ relative, the least-squares regression was repeated omitting Fe from the calculation, which resulted in considerably smaller residuals without significant change of modal proportions. For experimental charges with spinel grains that were too small to be analysed by electron microprobe, spinel analyses from other experiments at similar conditions were used for the mass balance calculation (Table 2).

\section{EXPERIMENTAL RESULTS}

Conditions, phase assemblages and calculated proportions of experimental runs, as well as relative iron losses $(\triangle \mathrm{Fe} \%$ ), are reported in Table 2. The compositions of quenched glasses and crystalline phases are listed in Table 3. Fe $/ \mathrm{Mg}$ mineral-melt partition coefficients for olivine and pyroxenes, $\mathrm{Al}_{2} \mathrm{O}_{3}, \mathrm{TiO}_{2}$ and $\mathrm{Na}_{2} \mathrm{O} K_{\mathrm{d}}$ values for pyroxenes, and $\mathrm{CaO} /\left(\mathrm{Na}_{2} \mathrm{O}+\mathrm{K}_{2} \mathrm{O}\right) K_{\mathrm{d}}$ values for plagioclase are listed in Table 4.

\section{Iron loss}

In most runs a limited amount of Fe was lost to the platinum capsule. Fe loss occurs through small cracks in the inner graphite capsule connecting the liquid with the outer Pt-capsule. In all runs relative Fe losses, estimated on the basis of mass balance calculations, were lower than 8.0\%. In some runs (SV99, SV101, SV103, SV104) small amounts of $\mathrm{Fe}$ gain were calculated $(<-0.62 \%$ relative $)$, 
Table 2: Experimental run conditions, phase assemblages and proportions

\begin{tabular}{|c|c|c|c|c|c|c|c|}
\hline Run no. & Starting material & $T\left({ }^{\circ} \mathrm{C}\right)$ & Time (h) & Run products & Phase proportions (wt \%) & $\Sigma R^{2}$ & $\Delta \mathrm{Fe}(\%)$ \\
\hline \multicolumn{8}{|c|}{ Equilibrium crystallization } \\
\hline SV75 & HK\#19.1 & 1240 & 8.0 & liq, ol, sp & $95 \cdot 7(7): 3 \cdot 2(6): 1 \cdot 0(5)$ & 0.36 & $5 \cdot 38$ \\
\hline SV89 & HK\#19.1 & 1210 & 20.5 & liq, $c p x, o p x, p l g, s p$ & $71 \cdot 5(21): 14 \cdot 3(23): 11 \cdot 0(17): 2 \cdot 2(14): 1 \cdot 0(8)$ & 0.03 & $4 \cdot 14$ \\
\hline SV90 & HK\#19.1 & 1180 & 72.5 & liq, $c p x, o p x, p l g, s p$ & $45 \cdot 8(15): 38 \cdot 6(8): 3 \cdot 8(6): 4 \cdot 4(10): 7 \cdot 4(2)$ & 0.04 & 0.28 \\
\hline SV79 & HK\#19.1 & 1150 & $78 \cdot 0$ & liq, $c p x, o p x, p l g, s p$ & $23 \cdot 9(6): 48 \cdot 4(2): 4 \cdot 4(2): 14 \cdot 3(3): 9 \cdot 0(1)$ & 0.00 & 0.07 \\
\hline \multicolumn{8}{|c|}{ Fractional crystallization } \\
\hline SV76 & HK\#19.2 & 1270 & $5 \cdot 0$ & liq, ol, sp & $94 \cdot 0(9): 4 \cdot 6(8): 1 \cdot 4(7)$ & 0.69 & 8.00 \\
\hline SV96 & $7 \mathrm{Fr} 1$ & 1240 & 7.5 & liq, ol, $c p x, s p$ & $88 \cdot 0(10): 3 \cdot 3(4): 6 \cdot 8(11): 1 \cdot 9(2)$ & 0.06 & 1.01 \\
\hline SV97 & $7 \mathrm{Fr} 2$ & 1210 & $20 \cdot 0$ & liq, $c p x, o p x, p l g, s p$ & $69 \cdot 9(11): 15 \cdot 6(6): 6 \cdot 6(5): 6 \cdot 7(7): 1 \cdot 1(1)$ & 0.02 & 0.11 \\
\hline sv99 & $7 \mathrm{Fr} 3$ & 1180 & $46 \cdot 2$ & liq, $c p x, p l g, s p$ & $68 \cdot 2(9): 16 \cdot 4(5): 14 \cdot 6(5): 0 \cdot 7(1)$ & 0.03 & -0.62 \\
\hline SV101 & $7 \mathrm{Fr} 4$ & 1150 & $114 \cdot 2$ & liq, $c p x, p l g, s p$ & $39 \cdot 6(13): 30 \cdot 3(7): 27 \cdot 2(7): 2 \cdot 9(2)$ & 0.06 & -0.03 \\
\hline SV103 & $7 F r 5$ & 1120 & $162 \cdot 0$ & liq, $c p x, p l g, s p$ & $59 \cdot 4(8): 17 \cdot 5(5): 21 \cdot 8(4): 1 \cdot 3(1)$ & 0.02 & 0.04 \\
\hline SV104 & $7 \mathrm{Fr} 6$ & 1090 & $145 \cdot 0$ & liq, cpx, plg, sp, ilm & $64 \cdot 9(40): 13 \cdot 6(20): 20 \cdot 2(23): 0 \cdot 6(4): 0 \cdot 7(5)$ & 0.29 & -0.22 \\
\hline SV107 & $7 \mathrm{Fr} 7$ & 1060 & $167 \cdot 0$ & liq, cpx, plg, sp, ilm & $52 \cdot 9(28): 20 \cdot 0(13): 21 \cdot 6(18): 1 \cdot 7(3): 3 \cdot 7(3)$ & 0.13 & 0.23 \\
\hline
\end{tabular}

Starting materials 7Fr1 and 7Fr7 correspond to the glass compositions of the previous, $30^{\circ} \mathrm{C}$ higher temperature, experiment (see Tables 1 and 3). $\Delta \mathrm{Fe}$ is the difference between the $\mathrm{FeO}$ content of the bulk starting composition and the $\mathrm{FeO}$ in the bulk composition calculated by mass balance. Negative values indicate relative iron gain (relative weight per cent). Phase proportions are calculated by least-squares regressions. $\Sigma R^{2}$ indicates the quality of the regression. Numbers in parentheses represent the $2 \sigma$ error from the regression analysis. Accordingly, $95.7(7)$ should be read as $95.7 \pm 0.7$.

which are statistically insignificant. Small iron losses or gains justify our assumption that a relatively constant bulk composition was maintained during the experiments.

\section{Attainment of equilibrium}

Figure 1 displays the $\mathrm{Fe}-\mathrm{Mg}$ partitioning behaviour between the solid phases olivine, cpx, opx and the quenched liquids expressed as $K_{\mathrm{d}}$ values (all $\mathrm{Fe}$ as $\mathrm{Fe}^{2+}$ ) plotted against temperature. They indicate a close approximation to equilibrium. The $\mathrm{Fe} / \mathrm{Mg}$ olivine-liquid $K_{\mathrm{d}}$ is 0.31 for two fractional crystallization experiments, and 0.32 for one equilibrium crystallization experiment. These values are systematically lower than at $1.0 \mathrm{GPa}$ (0.34-0.33, Villiger et al., 2004). This is consistent with the $K_{\mathrm{d}}$ values calculated for basaltic compositions at $0.7 \mathrm{GPa}$ (Ulmer, 1989) with an $f \mathrm{O}_{2}$ constrained by the $\mathrm{C}-\mathrm{CO}_{2}-$ $\mathrm{CO}$ equilibrium in this temperature range $\left(K_{\mathrm{d}}=0.32\right)$. The pyroxene-liquid $\mathrm{Fe}-\mathrm{Mg} K_{\mathrm{d}}$ values in our experiments are in the same range as those reported from mantle partial melting experiments performed by Gaetani \& Grove (1998). For coexisting pyroxenes, $\mathrm{Fe}-\mathrm{Mg} K_{\mathrm{d}}$ values for orthopyroxene (opx) tend to be lower than for clinopyroxene (cpx). Pyroxene-melt $\mathrm{Fe}-\mathrm{Mg} K_{\mathrm{d}}$ values in the equilibrium crystallization experiments decrease from 0.32 and 0.25 in a temperature interval from $1210^{\circ} \mathrm{C}$ and $1150^{\circ} \mathrm{C}$ whereas for the fractional crystallization experiments this trend is less obvious for cpx-melt $K_{\mathrm{d}}$ values $(0 \cdot 32-0 \cdot 26)$ over the temperature interval $1240^{\circ} \mathrm{C}$ to $1060^{\circ} \mathrm{C}$. Additionally, we observe a decrease of $K_{\mathrm{d}}$ with increasing differentiation consistent with increasing contents of $\mathrm{Na}_{2} \mathrm{O}$ and $\mathrm{K}_{2} \mathrm{O}$ and increasing degree of polymerization of coexisting liquids in equilibrium crystallization experiments as observed, for example, by Kushiro \& Mysen (2002) for olivine-liquid $\mathrm{Fe}-\mathrm{Mg}$ partitioning.

In most experimental charges pyroxenes and plagioclase exhibit some chemical zoning although, in general, the range of variation is small. In particular, the opx in run $\mathrm{SV} 97\left(1210^{\circ} \mathrm{C}\right.$, fractionation experiment) shows sector zoning with Al-poor $\left(2.5 \pm 0.3 \mathrm{wt} \% \mathrm{Al}_{2} \mathrm{O}_{3}\right)$ and Al-rich sectors $\left(4.5 \pm 0.2\right.$ wt $\left.\% \quad \mathrm{Al}_{2} \mathrm{O}_{3}\right)$. Plagioclase shows normal zoning with decreasing anorthite content from core to rim (e.g. SV97 plagioclase profile from core to rim: $\left.X_{\mathrm{An}} 0 \cdot 73-0 \cdot 68\right)$. In these rare cases, average mineral compositions were used in the least-squares regression calculations to estimate the modal proportions of phases in the charges (see above). Anorthite-rich cores observed in some experiments originate from the pure anorthite seeds, indicating that chemical equilibrium was not always fully achieved. In such cases, rim compositions have been analysed. The regular behaviour of major and minor element partitioning between cpx and plg and the consistency of the liquid evolution with temperature (Table 4) indicates a close approximation to equilibrium. An additional indication for an overall successful approach to equilibrium is provided by the quality of mass balance calculations 
Table 3: Electron microprobe analyses of run products in wt \%

\begin{tabular}{|c|c|c|c|c|c|c|c|c|c|c|c|c|c|c|}
\hline Run no. & Phase & $n$ & $\mathrm{SiO}_{2}$ & $\mathrm{TiO}_{2}$ & $\mathrm{Al}_{2} \mathrm{O}_{3}$ & $\mathrm{Cr}_{2} \mathrm{O}_{3}$ & $\mathrm{FeO}_{\text {tot }}$ & $\mathrm{MnO}$ & $\mathrm{MgO}$ & $\mathrm{CaO}$ & $\mathrm{Na}_{2} \mathrm{O}$ & $\mathrm{K}_{2} \mathrm{O}$ & Total & Mg-no. $/ X_{\mathrm{An}}$ \\
\hline \multicolumn{15}{|c|}{ Equilibrium crystallization } \\
\hline \multirow[t]{3}{*}{ SV75 } & melt & 11 & $49 \cdot 10(32)$ & $0.58(2)$ & $14.93(20)$ & $0.29(2)$ & $6.89(18)$ & $0.20(3)$ & $11.44(8)$ & $12 \cdot 60(12)$ & $1.86(6)$ & $0.08(1)$ & $97.97(75)$ & 0.75 \\
\hline & ol & 16 & $40 \cdot 67(5)$ & $0.02(0)$ & $0.06(0)$ & $0.21(0)$ & $9.59(2)$ & $0.20(0)$ & 49.64(9) & $0.37(0)$ & $<0.01$ & $<0.01$ & $100 \cdot 77(12)$ & 0.89 \\
\hline & $\mathrm{sp}$ & 5 & $0.29(27)$ & $0.24(1)$ & $30 \cdot 21(112)$ & $38 \cdot 79(105)$ & $10.94(23)$ & $0.07(14)$ & $17 \cdot 55(17)$ & $0.33(4)$ & $0.01(2)$ & $<0.01$ & $98.59(52)$ & 0.74 \\
\hline \multirow[t]{5}{*}{ SV89 } & melt & 8 & $50 \cdot 72(30)$ & $0.72(6)$ & $16.91(22)$ & $0 \cdot 10(3)$ & $7 \cdot 69(22)$ & $0.21(8)$ & $8.72(24)$ & $12 \cdot 26(19)$ & $2 \cdot 13(10)$ & $0.11(2)$ & $99.55(74)$ & 0.67 \\
\hline & $\mathrm{cpx}$ & 11 & $52 \cdot 45(35)$ & $0.25(2)$ & $5 \cdot 08(51)$ & 1. $02(10)$ & $5 \cdot 64(63)$ & $0.22(4)$ & $19.86(24)$ & 16.53(53) & $0.31(2)$ & $<0.01$ & $101 \cdot 48(11)$ & 0.86 \\
\hline & opx & 13 & $53.82(22)$ & $0 \cdot 14(1)$ & $4.95(26)$ & $1 \cdot 15(5)$ & $7 \cdot 38(23)$ & $0.23(1)$ & $29 \cdot 68(27)$ & $3 \cdot 02(14)$ & $0.07(2)$ & $0.01(0)$ & $100 \cdot 47(52)$ & 0.88 \\
\hline & plg & 12 & $49 \cdot 63(47)$ & $0.03(1)$ & $31 \cdot 34(25)$ & $0.01(1)$ & $0.39(13)$ & $0.02(1)$ & $0.25(3)$ & $15 \cdot 86(32)$ & 3. 02(6) & $0.03(1)$ & $100 \cdot 61(26)$ & 0.74 \\
\hline & $\mathrm{sp}^{*} \mathrm{SV} 18$ & 8 & $0.17(5)$ & $0.15(1)$ & $58 \cdot 24(126)$ & $9 \cdot 15(134)$ & $11.41(15)$ & $0.31(4)$ & $18 \cdot 83(39)$ & $0.18(2)$ & $0.02(2)$ & $<0.01$ & $98.46(56)$ & 0.75 \\
\hline \multirow[t]{5}{*}{ Sv90 } & melt & 12 & $52 \cdot 08(21)$ & $1 \cdot 14(3)$ & $16 \cdot 76(20)$ & $0.06(1)$ & $8.10(11)$ & $0 \cdot 17(3)$ & $7.05(10)$ & $10.53(7)$ & $2 \cdot 81(10)$ & $0.17(1)$ & $98.88(39)$ & 0.61 \\
\hline & $\mathrm{cpx}$ & 11 & $53.34(35)$ & $0.37(5)$ & $3.61(38)$ & $0.51(6)$ & $6 \cdot 26(26)$ & $0.21(5)$ & $18 \cdot 78(51)$ & $17.50(47)$ & $0.40(2)$ & $0.01(1)$ & $101 \cdot 02(50)$ & 0.84 \\
\hline & opx & 10 & $55 \cdot 29(43)$ & $0.23(4)$ & $3.62(48)$ & $0.60(8)$ & $9.22(14)$ & $0.22(3)$ & $29 \cdot 63(35)$ & $2 \cdot 71(16)$ & $0.06(1)$ & $<0.01$ & $101.59(24)$ & 0.85 \\
\hline & plg & 10 & $52.99(48)$ & $0.05(1)$ & $30.04(28)$ & $0.01(1)$ & $0.41(12)$ & $0.01(1)$ & $0.21(3)$ & $13 \cdot 53(31)$ & $3.95(17)$ & $0.05(1)$ & $101 \cdot 26(31)$ & 0.65 \\
\hline & $\mathrm{sp}^{*} \mathrm{SV} 21$ & 7 & $0.13(4)$ & $0 \cdot 14(1)$ & $63 \cdot 21(170)$ & $3.47(159)$ & $13 \cdot 77(19)$ & $0.05(4)$ & $19.48(28)$ & $0.12(1)$ & $0.02(2)$ & $<0.01$ & $100 \cdot 55(28)$ & 0.72 \\
\hline \multirow[t]{5}{*}{ SV79 } & melt & 10 & $54.74(21)$ & $1.47(5)$ & $14 \cdot 86(8)$ & $0.04(2)$ & $7.99(6)$ & $0 \cdot 16(3)$ & $4 \cdot 70(13)$ & $9 \cdot 06(7)$ & 3. 07(8) & $0.31(2)$ & $96 \cdot 40(34)$ & 0.51 \\
\hline & $\mathrm{cpx}$ & 12 & $52.81(33)$ & $0.46(7)$ & $2.51(19)$ & $0.57(11)$ & $7.72(48)$ & $0 \cdot 19(2)$ & $18.44(50)$ & 16.68(96) & $0.35(3)$ & $0.01(1)$ & $99.80(33)$ & 0.81 \\
\hline & opx & 16 & $54.03(32)$ & $0.30(2)$ & $2 \cdot 44(20)$ & $0.42(3)$ & $11.94(62)$ & $0.23(2)$ & $29 \cdot 08(18)$ & $2 \cdot 64(11)$ & $0.05(1)$ & $0 \cdot 01(0)$ & $101 \cdot 45(52)$ & 0.81 \\
\hline & plg & 9 & $52 \cdot 02(29)$ & $0.07(1)$ & $29.78(56)$ & $0.02(1)$ & $0.40(4)$ & $0.02(0)$ & $0.15(2)$ & $12 \cdot 76(48)$ & $4.27(21)$ & $0.05(1)$ & $99.57(57)$ & 0.62 \\
\hline & $\mathrm{sp}$ & 4 & $0.46(29)$ & $0.12(2)$ & $67.23(78)$ & $0.12(13)$ & $14 \cdot 10(73)$ & $0.10(4)$ & $18 \cdot 34(35)$ & $0.24(10)$ & $0.02(2)$ & $0.01(1)$ & $97.37(14)$ & 0.70 \\
\hline \multicolumn{15}{|c|}{ Fractional crystallization } \\
\hline SV76 & liq & 10 & $49 \cdot 28(19)$ & $0.58(1)$ & $14 \cdot 31(11)$ & $0.31(3)$ & $6.65(7)$ & $0 \cdot 15(3)$ & $12 \cdot 60(14)$ & $11.94(5)$ & $1.61(5)$ & $0.09(1)$ & $97.52(46)$ & 0.76 \\
\hline \multirow[t]{2}{*}{$=7 \mathrm{Fr} 1$} & ol & 16 & $41 \cdot 14(35)$ & $0.01(1)$ & $0.05(1)$ & $0 \cdot 19(2)$ & $8.79(6)$ & $0 \cdot 14(2)$ & $50 \cdot 15(38)$ & $0.27(4)$ & $<0.01$ & $0.01(0)$ & $100 \cdot 75(49)$ & 0.91 \\
\hline & $\mathrm{sp}$ & 3 & $0.04(1)$ & $0.26(1)$ & $28.96(54)$ & $38.67(44)$ & $11 \cdot 01(17)$ & $0.21(0)$ & $20 \cdot 13(13)$ & $0.22(1)$ & $0.02(0)$ & $0.01(0)$ & $99.53(6)$ & 0.77 \\
\hline sv96 & liq & 10 & $51 \cdot 03(22)$ & $0.60(4)$ & $14 \cdot 84(16)$ & $0 \cdot 19(2)$ & $7 \cdot 28(7)$ & $0 \cdot 13(2)$ & $10 \cdot 67(7)$ & $12 \cdot 19(8)$ & $1.94(6)$ & $0.14(2)$ & $99 \cdot 01(40)$ & 0.72 \\
\hline \multirow[t]{3}{*}{$=7 \mathrm{Fr} 2$} & ol & 9 & $40 \cdot 97(5)$ & $0.01(1)$ & $0.05(0)$ & $0.15(1)$ & $10.41(8)$ & $0 \cdot 14(1)$ & $49 \cdot 19(18)$ & $0.37(2)$ & $0.01(1)$ & $<0.01$ & $101 \cdot 30(29)$ & 0.89 \\
\hline & $\mathrm{cpx}$ & 11 & $52 \cdot 32(47)$ & $0.26(9)$ & $4 \cdot 24(53)$ & $1.25(15)$ & 4. 01(45) & $0 \cdot 11(1)$ & $19.98(41)$ & $18 \cdot 11(54)$ & $0.31(3)$ & $<0.01$ & $100 \cdot 60(25)$ & 0.90 \\
\hline & $\mathrm{sp}$ & 6 & $0.34(21)$ & $0 \cdot 18(2)$ & $41.51(51)$ & $26 \cdot 73(61)$ & $11 \cdot 02(9)$ & $0 \cdot 14(2)$ & $19 \cdot 44(21)$ & $0.34(3)$ & $0.01(1)$ & $<0.01$ & 99.95(42) & 0.78 \\
\hline
\end{tabular}




\begin{tabular}{|c|c|c|c|c|c|c|c|c|c|c|c|c|c|c|}
\hline sV97 & liq & 18 & $51 \cdot 16(19)$ & $0.73(3)$ & $15.95(20)$ & $0.05(2)$ & $7.98(14)$ & $0.14(3)$ & $7.92(10)$ & $11.71(9)$ & $2.51(10)$ & $0.21(2)$ & $98 \cdot 37(54)$ & 0.64 \\
\hline \multirow[t]{4}{*}{$=7 \mathrm{Fr} 3$} & $\mathrm{cpx}$ & 14 & $51.92(29)$ & $0.28(3)$ & $4 \cdot 30(38)$ & $0.49(11)$ & $5.98(53)$ & $0 \cdot 17(2)$ & $18.86(25)$ & $17 \cdot 78(32)$ & $0.37(3)$ & $0.01(1)$ & $100 \cdot 15(21)$ & 0.85 \\
\hline & opx & 18 & $54.35(50)$ & $0.14(2)$ & $3.92(57)$ & $0.50(7)$ & $8.48(52)$ & $0 \cdot 17(2)$ & $29.65(30)$ & $2 \cdot 65(16)$ & $0.04(1)$ & $0.01(0)$ & $99.91(21)$ & 0.86 \\
\hline & plg & 23 & $50 \cdot 39(47)$ & $0.04(1)$ & $28 \cdot 62(82)$ & $0.02(2)$ & $0.40(6)$ & $0.01(1)$ & $0.37(8)$ & $15 \cdot 27(23)$ & $3.46(13)$ & $0.06(1)$ & $98.65(116)$ & 0.71 \\
\hline & $\mathrm{sp}$ & 5 & $0.09(2)$ & $0.12(2)$ & $65.87(17)$ & $0.01(1)$ & $12.96(21)$ & $0.15(4)$ & $19 \cdot 65(15)$ & $0.14(1)$ & $<0.01$ & $0.01(1)$ & $99 \cdot 01(24)$ & 0.73 \\
\hline SV99 & liq & 13 & $51.80(27)$ & $0.95(3)$ & $15 \cdot 77(11)$ & $0.02(2)$ & $9.82(14)$ & $0 \cdot 16(3)$ & $7 \cdot 20(12)$ & $10 \cdot 22(7)$ & $2.88(13)$ & $0.31(3)$ & $99 \cdot 14(41)$ & 0.57 \\
\hline \multirow[t]{3}{*}{$=7 \mathrm{Fr} 4$} & $\mathrm{cpx}$ & 15 & $52.64(28)$ & $0.42(4)$ & $3.59(29)$ & $0.13(2)$ & $7.61(60)$ & $0 \cdot 19(2)$ & $17 \cdot 72(31)$ & $18 \cdot 52(74)$ & $0.38(5)$ & $0.01(1)$ & $101 \cdot 20(40)$ & 0.81 \\
\hline & plg & 34 & $52.82(69)$ & $0.05(2)$ & $29 \cdot 28(48)$ & $0.01(1)$ & $0.47(8)$ & $0.02(1)$ & $0.25(6)$ & $13 \cdot 39(37)$ & $4 \cdot 31(20)$ & $0.09(1)$ & $100 \cdot 69(74)$ & 0.63 \\
\hline & $\mathrm{sp}$ & 3 & $0.08(3)$ & $0.23(2)$ & $66 \cdot 70(38)$ & $0.03(1)$ & $13.51(14)$ & $0 \cdot 11(1)$ & $19 \cdot 13(17)$ & $0 \cdot 15(1)$ & $<0.01$ & $<0.01$ & $99.91(35)$ & 0.72 \\
\hline SV101 & liq & 11 & $52.63(36)$ & $1.77(6)$ & $14.78(14)$ & $0.02(1)$ & $12 \cdot 35(15)$ & $0 \cdot 19(3)$ & $4 \cdot 32(7)$ & $8.22(6)$ & $3.47(10)$ & $0.74(3)$ & $98.50(45)$ & 0.38 \\
\hline \multirow[t]{3}{*}{$=7 \mathrm{Fr} 5$} & $\mathrm{cpx}$ & 12 & $51.73(28)$ & $0.73(8)$ & $2 \cdot 50(31)$ & $0.09(2)$ & 13.90(62) & $0 \cdot 36(3)$ & $16 \cdot 62(38)$ & $14 \cdot 34(81)$ & $0.37(4)$ & $0.01(1)$ & $100 \cdot 64(31)$ & 0.68 \\
\hline & plg & 10 & $56.65(31)$ & $0.08(1)$ & $27 \cdot 07(26)$ & $0.02(1)$ & $0.50(15)$ & $0.04(2)$ & $0.13(4)$ & $10 \cdot 27(24)$ & $5.85(9)$ & $0.27(1)$ & $100 \cdot 87(42)$ & 0.49 \\
\hline & $\mathrm{sp}$ & 4 & $0.31(13)$ & $0.48(19)$ & $63 \cdot 44(36)$ & $<0.1$ & $21.43(60)$ & $0 \cdot 18(2)$ & $14.69(29)$ & $0.17(4)$ & $0.02(1)$ & $<0.01$ & $100 \cdot 71(41)$ & 0.55 \\
\hline SV103 & liq & 10 & $53.13(24)$ & $2 \cdot 54(5)$ & $13 \cdot 63(12)$ & $0.02(2)$ & $14.42(9)$ & $0.22(3)$ & $2.90(5)$ & $6.91(4)$ & $3 \cdot 60(8)$ & $1 \cdot 25(2)$ & $98.61(41)$ & 0.26 \\
\hline \multirow[t]{3}{*}{$=7 \mathrm{Fr} 6$} & $\mathrm{cpx}$ & 22 & $50.78(21)$ & $0.89(7)$ & $2 \cdot 13(19)$ & $0.09(1)$ & $19 \cdot 19(108)$ & $0.42(3)$ & $14.50(51)$ & $12 \cdot 88(148)$ & $0.30(4)$ & $0.01(1)$ & $101 \cdot 20(37)$ & 0.57 \\
\hline & plg & 15 & $58.50(51)$ & $0.11(1)$ & $26 \cdot 25(30)$ & $0.01(1)$ & $0.71(26)$ & $0.02(1)$ & $0.08(3)$ & $8.99(26)$ & $6 \cdot 38(12)$ & $0.48(3)$ & $101 \cdot 54(36)$ & 0.44 \\
\hline & $\mathrm{sp}^{*} \mathrm{SV} 61$ & 9 & $0.15(7)$ & $0.69(9)$ & $60.64(30)$ & $0.02(1)$ & $29.45(24)$ & $0 \cdot 18(1)$ & $9.20(12)$ & $0.11(2)$ & $0.01(2)$ & $<0.01$ & $100 \cdot 44(32)$ & 0.36 \\
\hline SV104 & liq & 10 & $53 \cdot 28(30)$ & 3. 04(5) & $12.52(8)$ & $0.03(2)$ & $16 \cdot 35(19)$ & $0.21(3)$ & $1.77(6)$ & $5.98(6)$ & $3 \cdot 34(5)$ & $1.88(5)$ & $98 \cdot 39(27)$ & 0.16 \\
\hline \multirow[t]{4}{*}{$=7 \mathrm{Fr} 7$} & $\mathrm{cpx}$ & 10 & $48.54(26)$ & $1 \cdot 02(6)$ & $1.79(13)$ & $0.04(2)$ & $23 \cdot 62(80)$ & $0.46(3)$ & $9.90(29)$ & $13.90(82)$ & $0.30(2)$ & $0.02(1)$ & $99.58(47)$ & 0.43 \\
\hline & plg & 15 & $59.47(67)$ & $0.13(3)$ & $24 \cdot 46(53)$ & $0.01(1)$ & $0.75(22)$ & $0.01(1)$ & $0.06(3)$ & $7.39(54)$ & $6 \cdot 78(18)$ & 1. $05(12)$ & $100 \cdot 11(39)$ & 0.38 \\
\hline & $\mathrm{sp}^{*} \mathrm{SV} 63$ & 8 & $0.13(7)$ & $0.76(12)$ & $59.42(39)$ & $0.01(1)$ & $31.81(26)$ & $0.26(2)$ & $5.82(16)$ & $0.09(2)$ & $0.02(1)$ & $0.01(1)$ & $98 \cdot 32(47)$ & 0.25 \\
\hline & ilm & 6 & $0 \cdot 12(3)$ & $51.44(17)$ & $0.29(2)$ & $0.08(2)$ & $42 \cdot 61(29)$ & $0.44(3)$ & $1.92(4)$ & $0.38(4)$ & $0.03(3)$ & $0.02(0)$ & $97 \cdot 33(36)$ & 0.07 \\
\hline \multirow[t]{5}{*}{ SV107 } & liq & 24 & $56.77(40)$ & $1.82(6)$ & $11.61(8)$ & $0.01(1)$ & $15 \cdot 01(22)$ & $0.24(2)$ & $0.69(2)$ & $4.32(5)$ & $3 \cdot 13(5)$ & $3 \cdot 11(7)$ & $96 \cdot 71(29)$ & 0.08 \\
\hline & $\mathrm{cpx}$ & 10 & $48.78(26)$ & $0.93(5)$ & $1.59(9)$ & $0.03(2)$ & $29.48(109)$ & $0.45(6)$ & $5.67(21)$ & $12 \cdot 71(104)$ & $0.28(3)$ & $0.05(3)$ & $99.97(25)$ & 0.26 \\
\hline & plg & 12 & $61 \cdot 07(38)$ & $0 \cdot 10(3)$ & $23 \cdot 05(22)$ & $0.01(1)$ & $0.85(6)$ & $0.01(1)$ & $<0.01$ & $6 \cdot 04(28)$ & $6.51(7)$ & $1.88(13)$ & $99.51(27)$ & 0.33 \\
\hline & $\mathrm{sp}^{*} \mathrm{SV} 63$ & 8 & $0.13(7)$ & $0.76(12)$ & $59.42(39)$ & $0.01(1)$ & $31.81(26)$ & $0.26(2)$ & $5.82(16)$ & $0.09(2)$ & $0.02(1)$ & $0.01(1)$ & $98 \cdot 32(47)$ & 0.25 \\
\hline & ilm & 7 & $0.48(2)$ & $50.50(25)$ & $0.36(2)$ & $0.08(3)$ & $45.91(26)$ & $0.31(1)$ & 1. 02(8) & $0.29(2)$ & $0.04(2)$ & $0.06(0)$ & $99 \cdot 01(36)$ & 0.04 \\
\hline
\end{tabular}

$\mathrm{FeO}_{\text {tot }}$ and $\mathrm{Mg}$-number: all $\mathrm{Fe}$ as $\mathrm{Fe}^{2+}$. Numbers in parentheses indicate standard errors $(2 \sigma)$ from average analysis. Accordingly, $49 \cdot 10(32)$ should be read as $49.10 \pm 0.32$. Glass compositions referring to starting materials 7Fr1-7Fr7 are given in the column for run number. $n$, number of analyses. sp* indicates spinel analysis taken from other experimental runs for mass balance because in these runs spinels were too small to be analysed successfully (SV61, SV62: Villiger et al., 2004; SV18, SV21: unpublished data). 
Table 4: Distribution coefficients $\left(\mathrm{K}_{d}\right)$ between crystals and liquid of anhydrous experiments at $0.7 \mathrm{GPa}$

\begin{tabular}{|c|c|c|c|c|c|c|}
\hline \multirow[t]{2}{*}{ Run no. } & \multicolumn{2}{|l|}{$K_{\mathrm{d}}(\mathrm{Fe} / \mathrm{Mg})$} & $K_{\mathrm{d}}(\mathrm{Al})$ & \multirow{2}{*}{$\frac{K_{\mathrm{d}}(\mathrm{Ti})}{\mathrm{cpx}}$} & \multirow{2}{*}{$\frac{K_{\mathrm{d}}(\mathrm{Na})}{\mathrm{cpx}}$} & \multirow{2}{*}{$\frac{K_{\mathrm{d}}[\mathrm{Ca} /(\mathrm{Na}+\mathrm{K})]}{\mathrm{plg}}$} \\
\hline & ol $c p x$ & $o p x$ & $\mathrm{cpx}$ & & & \\
\hline
\end{tabular}

\begin{tabular}{|c|c|c|c|c|c|c|c|c|}
\hline \multicolumn{9}{|c|}{ Equilibrium crystallization } \\
\hline SV75 & \multicolumn{8}{|l|}{0.32} \\
\hline SV89 & & 0.32 & 0.28 & 0.30 & 0.29 & 0.35 & 0.15 & 0.95 \\
\hline SV90 & & 0.29 & 0.27 & 0.21 & 0.21 & 0.32 & 0.14 & 0.96 \\
\hline SV79 & & 0.25 & 0.24 & 0.16 & 0.16 & 0.30 & 0.11 & $1 \cdot 10$ \\
\hline \multicolumn{9}{|c|}{ Fractional crystallization } \\
\hline SV76 & 0.31 & & & & & & & \\
\hline SV96 & 0.31 & 0.29 & & 0.28 & & 0.43 & 0.16 & \\
\hline SV97 & & 0.32 & 0.28 & 0.27 & 0.24 & 0.38 & 0.14 & 1.01 \\
\hline SV99 & & 0.31 & & 0.23 & & 0.44 & 0.13 & 0.95 \\
\hline SV101 & & 0.29 & & 0.17 & & 0.41 & $0 \cdot 10$ & 0.85 \\
\hline SV103 & & 0.27 & & 0.15 & & 0.34 & 0.08 & 0.92 \\
\hline SV104 & & 0.26 & & 0.14 & & 0.33 & 0.09 & 0.85 \\
\hline SV107 & & 0.27 & & 0.13 & & 0.51 & 0.09 & 1.05 \\
\hline
\end{tabular}

$\mathrm{K}_{\mathrm{d}}(\mathrm{Fe} / \mathrm{Mg})$ calculated as $\mathrm{FeO}_{\text {xtal }} * \mathrm{MgO}_{\text {liq }} / \mathrm{FeO}_{\text {liq }} * \mathrm{MgO}_{\text {xtal }}$ $K_{\mathrm{d}}(\mathrm{Al})$ calculated as $\mathrm{Al}_{2} \mathrm{O}_{3 \times \text { tal }} / \mathrm{Al}_{2} \mathrm{O}_{3 \text { liq }} ; K_{\mathrm{d}}(\mathrm{Ti})$ as $\mathrm{TiO}_{2 \times \text { tal }} /$ $\mathrm{TiO}_{\text {2liq }} ; K_{\mathrm{d}}(\mathrm{Na})$ as $\mathrm{Na}_{2} \mathrm{O}_{\text {xtal }} / \mathrm{Na}_{2} \mathrm{O}_{\text {liqi }} ; K_{\mathrm{d}}[\mathrm{Ca} /(\mathrm{Na}+\mathrm{K})]$ calculated as $\quad\left[\mathrm{CaO}_{\mathrm{plg}} /\left(\mathrm{Na}_{2} \mathrm{O}_{\mathrm{plg}}+\mathrm{K}_{2} \mathrm{O}_{\mathrm{plg}}\right)\right] /\left[\mathrm{CaO}_{\mathrm{liq}}\right]$ $\left.\left(\mathrm{Na}_{2} \mathrm{O}_{\text {liq }}+\mathrm{K}_{2} \mathrm{O}_{\text {liq }}\right)\right]$.

performed with the average analyses of solid and quenched liquid phases listed in Table 2.

\section{Estimate of oxygen fugacity}

The oxygen fugacity of the piston cylinder experiments performed at $0.7 \mathrm{GPa}$ and $1300-1060^{\circ} \mathrm{C}$ was calculated with the empirical equations of Ulmer \& Luth (1991) and Frost \& Wood (1995), resulting in $\log f \mathrm{O}_{2}$ values of -8.8 to -11.2 with decreasing temperature. These values apply only if the hydrogen fugacity in our system is minimal and, therefore, the graphite stability reaches its maximum in the $\mathrm{C}-\mathrm{COH}$ system. To minimize the $f \mathrm{H}_{2}$ in our experiments we used $\mathrm{MgO}$ spacers around, below and above the capsule. Such assemblies provide very oxidizing conditions [several log units above the $\mathrm{Ni}-\mathrm{NiO}$ (NNO) equilibrium] and hence impose a rather low intrinsic hydrogen fugacity, as verified by Kägi (2000) for identical assemblies at 1.0 GPa pressure. In addition, this approach minimizes the production of $\mathrm{H}_{2} \mathrm{O}$ by hydrogen diffusion from the surrounding assembly material and provides a close approach to truly anhydrous (water-free) experiments. Small amounts of $\mathrm{CO}_{2}$ produced by oxidation of the graphite sample container cannot be completely excluded. The calculated oxygen fugacities of the quenched liquids in equilibrium with graphite are 2.1-1.7 log units below the quartz-fayalite-magnetite
(QFM) equilibrium. $\mathrm{Fe}^{3+} / \mathrm{Fe}^{2+}$ ratios calculated with the equation of Kress \& Carmichael (1991) vary between 0.032 and 0.026. Consequently, the molar Mg-number is calculated assuming all $\mathrm{Fe}$ as $\mathrm{Fe}^{2+}$. This varies between 0.75 and 0.51 in glasses obtained in the equilibrium crystallization experiments and from 0.76 to 0.09 in glasses produced in the fractional crystallization experiments.

The $f \mathrm{O}_{2}$ of both equilibrium and fractional crystallization experiments is buffered along the $\mathrm{C}-\mathrm{CO}-\mathrm{CO}_{2}$ equilibrium and, therefore, our experimental system represents an open system with respect to oxygen. Natural systems are often regarded as closed systems where the $\mathrm{Fe}^{3+} / \mathrm{Fe}^{2+}$ ratios of the crystallizing assemblage exert the dominant control on oxygen fugacity (e.g. Muan, 1958). However, our experiments were purposely run at low $f \mathrm{O}_{2}$ to keep the $\mathrm{Fe}^{3+} / \mathrm{Fe}^{2+}$ very low. Consequently, the open-system behaviour with respect to oxygen that is intrinsic to our experimental setup should not dramatically affect the liquid line of descent as inferred for more oxidizing systems (at $f \mathrm{O}_{2}$ corresponding to $\mathrm{FMQ}$ ) by Ghiorso \& Carmichael (1985).

\section{Grystallization sequence at $0.7 \mathrm{GPa}$}

The crystallization sequence for equilibrium crystallization experiments in the temperature interval between $1240^{\circ} \mathrm{C}$ and $1150^{\circ} \mathrm{C}$ starts with olivine (ol) and Cr-rich spinel (sp) as liquidus phases. Ol disappears from the crystallizing assemblage at $1210^{\circ} \mathrm{C}$, when cpx, plagioclase (plg) and opx form the crystallizing phase assemblage. Between $1210^{\circ} \mathrm{C}$ and $1150^{\circ} \mathrm{C}$ cpx, opx, plg and sp are the stable phases.

In the fractional crystallization series ol and sp are the liquidus phases at $1270^{\circ} \mathrm{C}$. Unlike the equilibrium crystallization experiments, the solid phases at $1240^{\circ} \mathrm{C}$ are $\mathrm{ol}$, cpx and sp. In this series, the disappearance of olivine and the first occurrence of plg are located at $1210^{\circ} \mathrm{C}$ co-precipitating with cpx, opx and sp. Between $1180^{\circ} \mathrm{C}$ and $1120^{\circ} \mathrm{C} \mathrm{cpx}$, plg and sp crystallized. At $1090^{\circ} \mathrm{C}$ and $1060^{\circ} \mathrm{C}$ ilmenite (ilm) is stable together with cpx, plg and sp.

\section{Calculated fractions of liquid and solid phases at $0.7 \mathrm{GPa}$}

The calculated melt fractions decrease from 95.7 to 23.9 wt $\%$ in equilibrium crystallization experiments between $1240^{\circ} \mathrm{C}$ and $1150^{\circ} \mathrm{C}$. Melt fractions in fractional crystallization experiments vary between 94.0 and $39.6 \mathrm{wt} \%$ in single fractionation steps. For these experiments it is more useful to use cumulative melt fractions, which represent the amount of liquid left relative to the initial starting composition (HK\# 19.2). These are plotted against temperature in Fig. 2 and range from 94.0 to $3.2 \mathrm{wt} \%$. Melt fractions calculated independently assuming $\mathrm{K}_{2} \mathrm{O}$ behaves as a completely incompatible oxide component are identical 

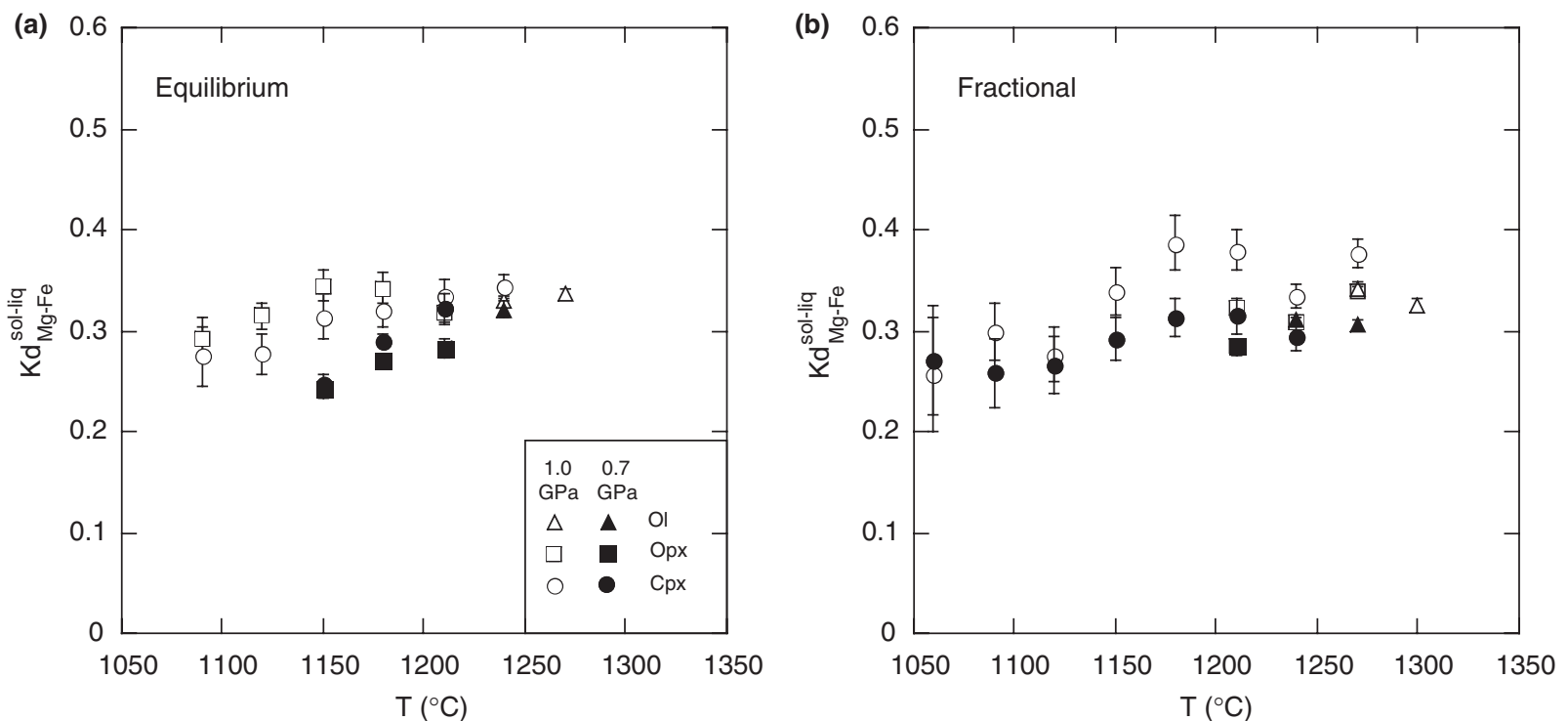

Fig. 1. $\mathrm{Fe}-\mathrm{Mg}$ partitioning $\left[K_{\mathrm{d}}=(\mathrm{Fe} / \mathrm{Mg})_{\text {solid }} /(\mathrm{Fe} / \mathrm{Mg})_{\text {liquid }}\right]$ between crystals and melt as a function of temperature $\left({ }^{\circ} \mathrm{C}\right)$ : (a) equilibrium crystallization at $0.7 \mathrm{GPa}$ (this study) and $1.0 \mathrm{GPa}$ (Villiger et al., 2004); (b) fractional crystallization at $0.7 \mathrm{GPa}$ (this study) and $1.0 \mathrm{GPa}$ (Villiger $e$ t al., 2004). Error bars indicate $2 \sigma$ standard errors.

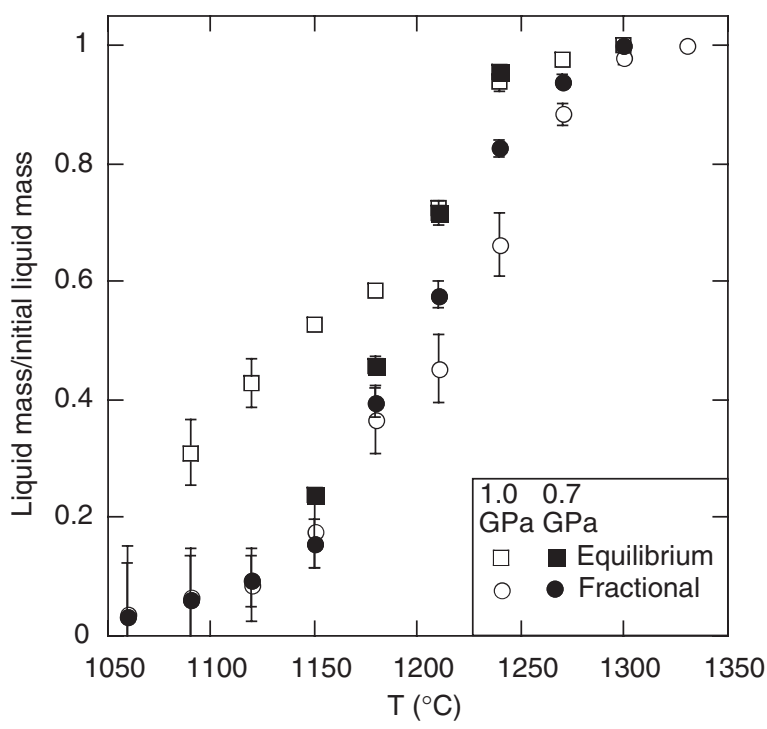

Fig. 2. Liquid mass/initial liquid mass vs temperature $\left({ }^{\circ} \mathrm{C}\right)$ for equilibrium and fractional crystallization experiments at 0.7 and 1.0 GPa. For fractionation experiments the cumulative melt fractions (product of melt fraction in each fractionation step) are plotted. Error bars indicate $2 \sigma$ standard errors calculated from the leastsquares regression analysis (Table 2). Data for equilibrium and fractional crystallization experiments at $1.0 \mathrm{GPa}$ are taken from Villiger et al. (2004).

within error for equilibrium crystallization experiments at $0.7 \mathrm{GPa}$ and for both experimental series at $1.0 \mathrm{GPa}$ (Villiger et al., 2004). They are less accurate for fractional crystallization experiments at 0.7 GPa because higher fractions of $\mathrm{K}_{2} \mathrm{O}$ are dissolved in plagioclase as an orthoclase component (see discussion of plagioclase compositions). The slopes of the trends in Fig. 2 define the crystallization rates per degree Celsius. The crystallization rates for both equilibrium and fractional processes at $0.7 \mathrm{GPa}$ increase with the onset of plagioclase precipitation, similar to calculated liquid mass/initial liquid mass at $200 \mathrm{MPa}$ (Kelemen \& Aharonov, 1998), whereas at $1.0 \mathrm{GPa}$ an increase of the crystallization rate is observed with the crystallization of orthopyroxene (Villiger et al., 2004).

Figure 3 displays stack diagrams of calculated fractions of liquid and solid phases from fractional (Fig. 3a) and equilibrium crystallization (Fig. 3b) experiments at $0.7 \mathrm{GPa}$. Melt and solid fractions of fractional (Fig. 3c) and equilibrium crystallization experiments (Fig. 3d) at $1.0 \mathrm{GPa}$ are given for comparison. For fractional crystallization experiments cumulative solid masses have been calculated and are shown in Fig. 3. Every single phase of each fractionation step is multiplied by the accumulated liquid mass and added to the masses of the previous fractionation step.

At $0.7 \mathrm{GPa}$ near-perfect fractional crystallization was simulated in seven steps between $1270^{\circ} \mathrm{C}$ and $1060^{\circ} \mathrm{C}$, resulting in the crystallization of $96.8 \mathrm{wt} \%$ of solid phases with respect to the initial mass of liquid (HK\#19.2). At $1060^{\circ} \mathrm{C}$ the accumulated solids are composed of 7.7 wt $\%$ ol, 5.5 wt $\%$ opx, 46 wt $\%$ cpx, $31.1 \mathrm{wt} \% \mathrm{plg}, 6.0 \mathrm{wt} \% \mathrm{sp}$ and $0.3 \mathrm{wt} \%$ ilm. At $1.0 \mathrm{GPa}$ near-perfect fractional crystallization of the same starting composition in nine steps between $1300^{\circ} \mathrm{C}$ and $1060^{\circ} \mathrm{C}$ resulted in 96.3 wt \% of solid phases 

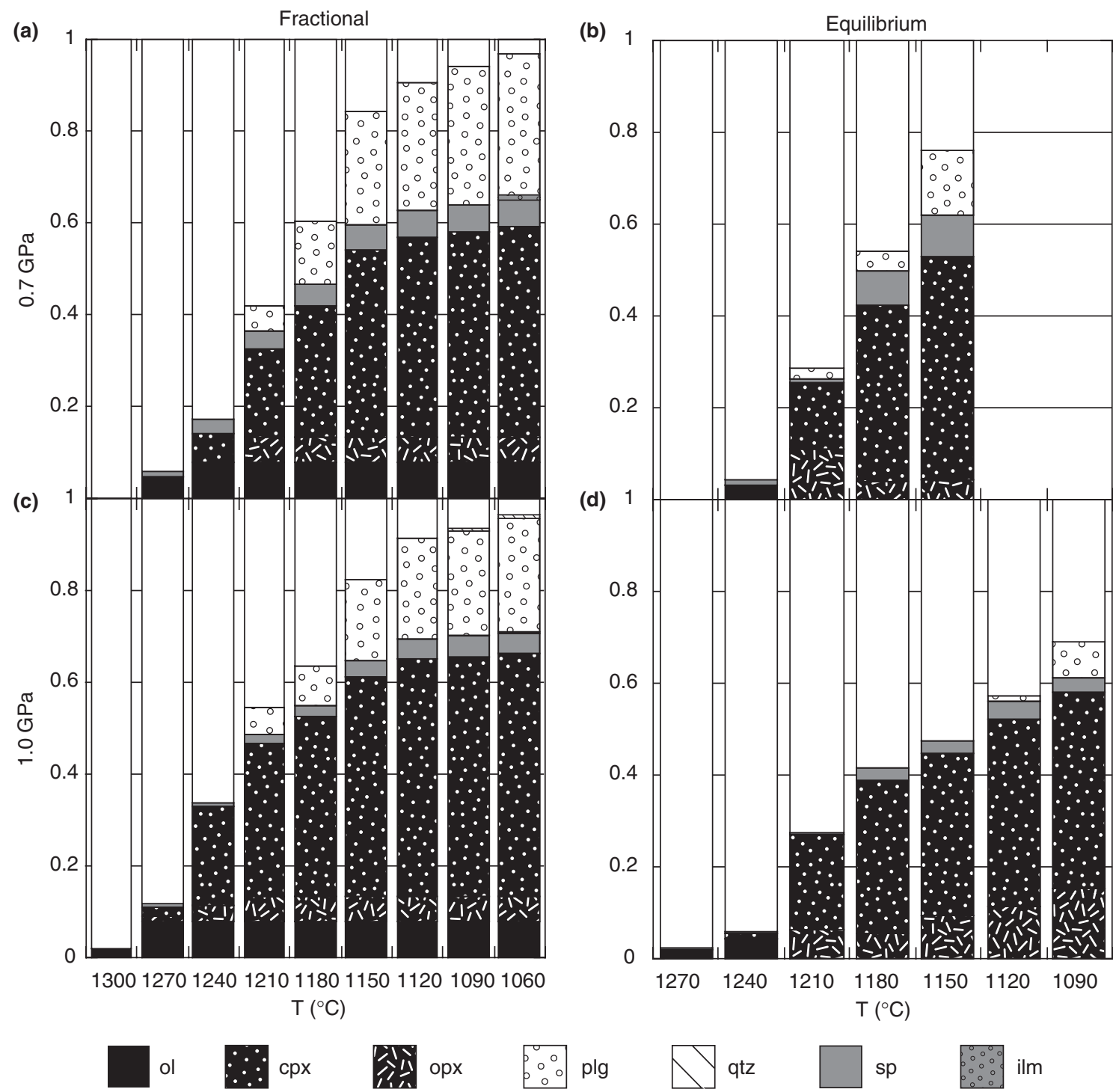

Fig. 3. Bar diagrams displaying melt and solid fractions at each experimental temperature for: (a) fractional crystallization experiments at $0.7 \mathrm{GPa}$; (b) equilibrium crystallization experiments at $0.7 \mathrm{GPa}$; (c) fractional crystallization experiments at $1.0 \mathrm{GPa}$; (d) equilibrium crystallization experiments at $1.0 \mathrm{GPa}$. Experimental data at $1.0 \mathrm{GPa}$ are taken from Villiger et al. (2004). For fractionation experiments the cumulative melt $=$ product of melt fraction in each fractionation step and the solid fractions = product of solid fractions and the cumulative melt fraction added to the solid fractions of the previous fractionation step.

(Villiger et al., 2004). Compared with the new experimental series at $0.7 \mathrm{GPa}$ the total accumulated solids at $1 \mathrm{GPa}$ contain comparable amounts of ol $(7.7 \mathrm{wt} \%)$ and opx (5.4 wt \%), higher amounts of cpx (53 wt \%), lower amounts of plg $(24.8 \mathrm{wt} \%)$, sp $(4.6 \mathrm{wt} \%)$ and ilm $(0 \cdot 2 \mathrm{wt} \%)$, and, in addition, $0.5 \mathrm{wt} \%$ qtz.

The solid assemblages of the equilibrium crystallization experiments at $0.7 \mathrm{GPa}$ contain larger amounts of plg and sp than at $1.0 \mathrm{GPa}$. Despite the positive Clapeyron slope of the liquidus, earlier crystallization of plg at $0.7 \mathrm{GPa}\left(1210^{\circ} \mathrm{G}\right)$ compared with the equilibrium crystallization experiments at $1.0 \mathrm{GPa}\left(1120^{\circ} \mathrm{C}\right)$ leads to more efficient crystallization at a given (sub-liquidus) temperature, which is clearly evident from comparison of Fig. 3b and Fig. 3d.

\section{Liquid lines of descent}

The anhydrous liquid lines of descent at $0.7 \mathrm{GPa}$ are shown in the $\mathrm{ol}^{-}{ }^{-} \mathrm{cpx}^{-} \mathrm{qtz}$ projection in Fig. 4: quenched glass compositions have been recalculated into mineral end-member components according to the method of Grove et al. (1992) and are projected onto the $\mathrm{ol}^{-} \mathrm{cpx}^{-} \mathrm{qtz}$ 

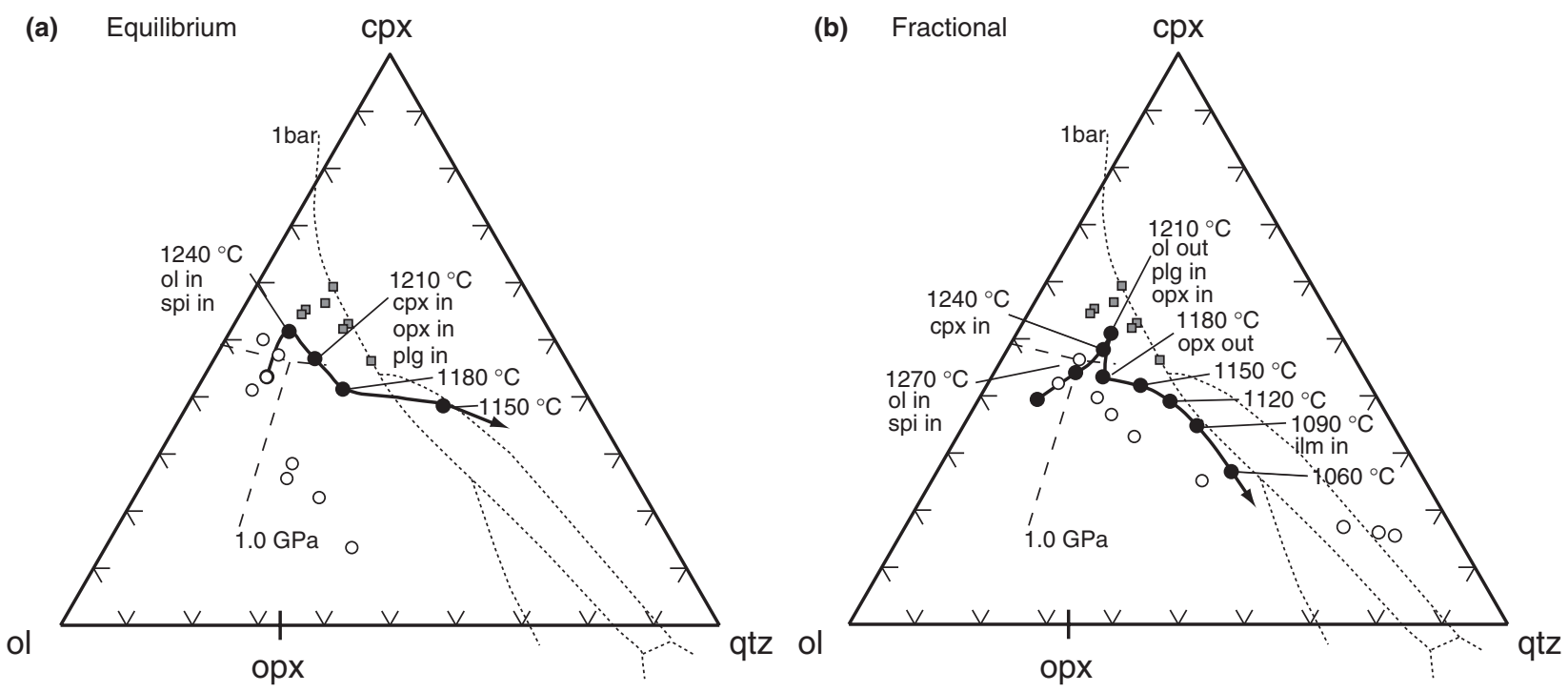

Fig. 4. Normative pseudo-ternary cpx-olivine-quartz diagram, illustrating the liquid lines of descent (glass compositions) for (a) anhydrous equilibrium and (b) fractional crystallization experiments. Experimental data at $0.7 \mathrm{GPa}$ (filled symbols) and at 1.0 GPa (open symbols; Villiger et al., 2004) are plotted. Data at 1 bar are taken from Yang et al. (1996). The 1 bar (dotted lines) and 1.0 GPa (dashed lines) phase boundaries are from Grove \& Baker (1984). Normalization into six components in oxygen units (ol, cpx, plg, qtz, orthoclase, oxide) is after Grove et al. (1992); compositions are projected from plagioclase, orthoclase and oxide. Temperatures and phase appearance (in) or disappearance (out) are noted along the liquid lines of descent for each projected $0.7 \mathrm{GPa}$ melt composition.

plane of the basalt tetrahedron from a normative oxide phase and feldspar. The liquids of equilibrium and fractional crystallization at $0.7 \mathrm{GPa}$ evolve from olivinenormative to quartz-normative compositions. They follow similar trends with decreasing temperature, but the liquids of the equilibrium crystallization experiments evolve towards more cpx-rich compositions, as a result of higher amounts of opx crystallized in the $1210^{\circ} \mathrm{C}$ experiment and large amounts of spinel crystallized in subsequent steps.

\section{Liquid compositions}

Figure $5 \mathrm{a}-\mathrm{f}$ displays some of the key features of the melt compositions. Selected major element abundances (expresses as wt \% oxides) in quenched glasses are plotted against their degree of differentiation expressed as Mg-number [=molar $\mathrm{Mg} /(\mathrm{Mg} / \mathrm{Fe})$, all $\mathrm{Fe}$ as $\mathrm{Fe}^{2+}$. Fractional and equilibrium crystallization experiments show slightly diverging differentiation trends at $0.7 \mathrm{GPa}$. $\mathrm{SiO}_{2}$ (Fig. 5a) increases in fractional crystallization experiments in the first two differentiation steps where ol and sp, and ol, cpx and sp crystallize, followed by a rather large temperature range $\left(1210-1090^{\circ} \mathrm{C}\right)$ where $\mathrm{SiO}_{2}$ enrichment in the liquids is moderate (52.0-54.2 wt \%). The appearance of ilm in the last fractionation step $\left(1060^{\circ} \mathrm{C}\right)$ leads to an increase of the $\mathrm{SiO}_{2}$ content in the liquid to 58.7 wt \%. Reduced amounts of plg crystallization as well as higher proportions of sp (Fig. 3) in the equilibrium crystallization experiments result in a continuous increase in $\mathrm{SiO}_{2}$ between $1240^{\circ} \mathrm{C}$ and $1150^{\circ} \mathrm{C}$, reaching 56.8 wt \%. $\mathrm{CaO}$ contents reach their maxima at the onset of the crystallization of the first calcium-bearing phase (cpx) and, thereafter, decrease monotonically with increasing differentiation in both crystallization series (Fig. 5b). Maximum values of 12.3 wt \% in fractional and $12.9 \mathrm{wt} \%$ in equilibrium crystallization experiments are obtained. $\mathrm{Al}_{2} \mathrm{O}_{3}$ contents initially increase in both series and reach their maximum at the onset of plg precipitation (Fig. 5c); a higher maximum is reached in equilibrium $(17.0 \mathrm{wt} \%)$ than in fractional crystallization experiments $(16.2 \mathrm{wt} \%)$ as a result of delayed plg crystallization. Iron, plotted as $\mathrm{FeO}_{\text {tot }}\left(\right.$ all $\mathrm{Fe}$ as $\mathrm{Fe}^{2+}$ ), and $\mathrm{TiO}_{2}$ monotonically increase to values of 16.7 and 3.1 wt $\%$, respectively, in fractional crystallization experiments and decrease in the last fractionation step as a result of the crystallization of ilm. With decreasing $\mathrm{Mg}$ number, $\mathrm{FeO}_{\text {tot }}$ of the equilibrium crystallization experiments follows an evolutionary curve with a flatter slope than in the fractional crystallization experiments, whereas $\mathrm{TiO}_{2}$ shows slightly stronger enrichment with increasing differentiation. The alkalis, $\mathrm{Na}_{2} \mathrm{O}$ and $\mathrm{K}_{2} \mathrm{O}$, increase similarly for both crystallization series with increasing differentiation. The $\mathrm{Na}_{2} \mathrm{O}$ concentrations in the liquids of the fractional crystallization experiments reach a maximum of $3.6 \mathrm{wt} \%$ at $1120^{\circ} \mathrm{C}$. The crystallization of large fractions of sodic plagioclase leads to a slight decrease of $\mathrm{Na}_{2} \mathrm{O}$ concentrations in the liquids between 

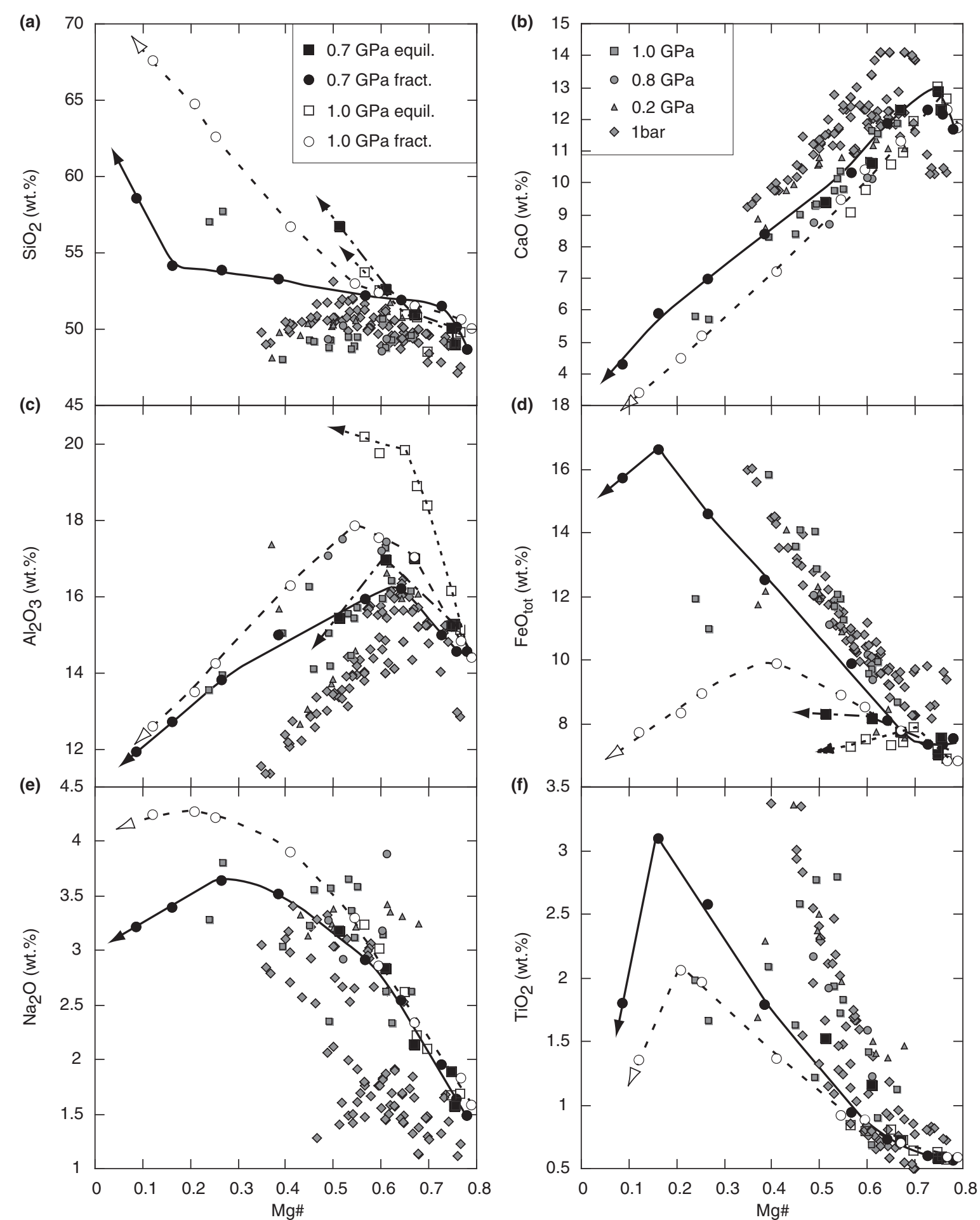

Fig. 5. Variations of selected oxides in experimental glasses in wt $\%$ plotted against $\mathrm{Mg}$-number $[=\operatorname{molar~} \mathrm{Mg} /(\mathrm{Mg}+\mathrm{Fe})]$ for equilibrium and fractional crystallization experiments at $0.7 \mathrm{GPa}$ (filled symbols, this study) and $1.0 \mathrm{GPa}$ (open symbols, Villiger et al., 2004): (a) $\mathrm{SiO}_{2}$; (b) $\mathrm{CaO}$; (c) $\mathrm{Al}_{2} \mathrm{O}_{3}$; (d) $\mathrm{FeO}_{\text {tot }}$; (e) $\mathrm{Na}_{2} \mathrm{O}$; (f) $\mathrm{TiO}_{2}$. Experimental data from the literature (grey filled symbols) at 1 bar are taken from Grove \& Bryan (1983), Tormey et al. (1987), Grove et al. (1990), Yang et al (1996), Sano et al. (2001) and Ulmer (unpublished data); at 0.2 GPa from Tormey et al. (1987) and Grove et al. (1992); at 0.8 GPa from Baker \& Eggler (1987) and Grove et al. (1990, 1992); at 1.0 GPa from Fram \& Longhi (1992) and Grove et al. (1992). Continuous lines indicate fractional crystallization trends at $0.7 \mathrm{GPa}$; dashed-dotted lines represent equilibrium crystallization trends at $0.7 \mathrm{GPa}$; long-dashed lines illustrate fractional crystallization trends at 1.0 GPa; short-dashed lines trace equilibrium crystallization trends at $1.0 \mathrm{GPa}$. Mg-number is calculated assuming all $\mathrm{Fe}$ as $\mathrm{Fe}^{2+}$. 
1120 and $1060^{\circ} \mathrm{G} . \mathrm{K}_{2} \mathrm{O}$ (not shown) behaves like a highly incompatible element, reaching $3 \cdot 1 \mathrm{wt} \%$ at $1060^{\circ} \mathrm{C}$.

\section{Mineral compositions at $0.7 \mathrm{GPa}$ \\ Pyroxenes}

Clinopyroxene compositions are illustrated in Fig. $6 \mathrm{a}^{-} \mathrm{c}$. Selected oxide components are plotted against $\mathrm{Mg}$-number. Clinopyroxene in the fractional and equilibrium crystallization experiments changes composition in accordance with the coexisting liquid composition. The Mg-number of the clinopyroxene from the fractional crystallization experiments decreases from 0.90 to 0.26 over the temperature interval between $1240^{\circ} \mathrm{C}$ and $1060^{\circ} \mathrm{C}$. Clinopyroxene in the equilibrium crystallization experiments shows $\mathrm{Mg}$-number variation between 0.86 and 0.81 at temperatures between $1210^{\circ} \mathrm{C}$ and $1150^{\circ} \mathrm{C}$. $\mathrm{Al}_{2} \mathrm{O}_{3}$ (Fig. 6a), $\mathrm{TiO}_{2}$ (Fig. 6b) and $\mathrm{Na}_{2} \mathrm{O}$ (Fig. 6c) show similar evolutionary trends for both crystallization series, with the development of bell-shaped curves exhibiting maxima in the fractional crystallization series at $4.30 \mathrm{wt} \%, 1.02 \mathrm{wt} \%$ and $0.38 \mathrm{wt} \%$, respectively. The $\mathrm{Al}_{2} \mathrm{O}_{3}$ and $\mathrm{Na}_{2} \mathrm{O}$ contents of cpx decrease with the onset of plagioclase precipitation and reach minimum values of 1.6 and $0.28 \mathrm{wt} \%$, respectively, at $1060^{\circ} \mathrm{C}$. The $\mathrm{TiO}_{2}$ contents of the cpx decrease after the onset of ilm crystallization and reach a value of $0.93 \mathrm{wt} \%$ at $1060^{\circ} \mathrm{C}$. Similar evolutionary trends are observed for the $\mathrm{cpx}$ of the equilibrium crystallization series: $\mathrm{Al}_{2} \mathrm{O}_{3}$ decreases from $5 \cdot 1$ to 2.5 wt $\%$ between $1210^{\circ} \mathrm{C}$ and $1150^{\circ} \mathrm{C}, \mathrm{TiO}_{2}$ increases from 0.25 to $0.46 \mathrm{wt} \%$ and $\mathrm{Na}_{2} \mathrm{O}$ increases from 0.31 to 0.40 at $1180^{\circ} \mathrm{C}$, followed by a decrease to 0.35 wt $\%$ at $1150^{\circ} \mathrm{C}$.

Orthopyroxenes (not shown) from the equilibrium crystallization experiments contain similar amounts of $\mathrm{Al}_{2} \mathrm{O}_{3}$ to the coexisting cpx varying from 4.9 to 2.4 wt $\%$. $\mathrm{TiO}_{2}$ and $\mathrm{Na}_{2} \mathrm{O}$ contents are significantly lower in the opx than in the coexisting cpx. $\mathrm{TiO}_{2}$ increases with increasing differentiation from 0.14 to $0.30 \mathrm{wt} \%$. In the fractional crystallization series, opx is stable with cpx in only a single experiment at $1210^{\circ} \mathrm{C}$ (SV97) and exhibits sector zoning. Zones of high $\mathrm{Al}_{2} \mathrm{O}_{3}$ content (4.3 wt \%) also contain higher $\mathrm{TiO}_{2}(0.14$ wt $\%, 0.11$ wt \%) and $\mathrm{Cr}_{2} \mathrm{O}_{3}\left(0.56\right.$ wt \%, 0.38 wt \%), but are lower in $\mathrm{SiO}_{2}$ $(54.6$ wt $\%, 56 \cdot 1$ wt $\%)$ than the zones of low $\mathrm{Al}_{2} \mathrm{O}_{3}(2.5$ wt \%). The average composition of this opx is slightly lower in $\mathrm{Al}_{2} \mathrm{O}_{3} \quad(3.9 \mathrm{wt} \%)$ and significantly lower in $\mathrm{TiO}_{2}(0.14$ wt $\%)$ and $\mathrm{Na}_{2} \mathrm{O}(0.04$ wt \%) than the coexisting cpx at a similar $\mathrm{Mg}$-number.

\section{Plagioclase}

Plagioclase compositions are illustrated in the albiteorthoclase-anorthite ternary diagram (Fig. 7). Plagioclase in the fractional crystallization experiments changes from bytownite to andesine in composition $\left(X_{\mathrm{An}}=0.71-0.33\right)$ with increasing differentiation. $\mathrm{K}_{2} \mathrm{O}$, soluble in plagioclase

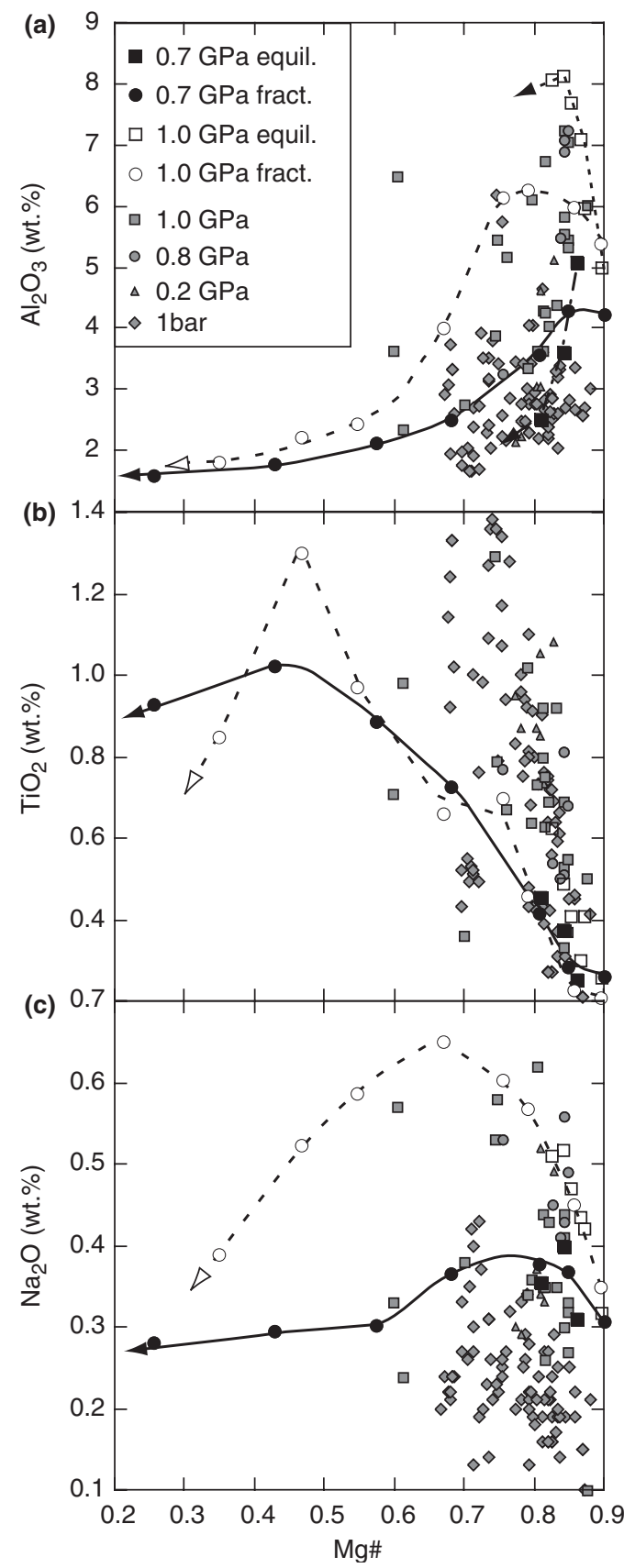

Fig. 6. Oxide variation diagrams for clinopyroxene plotted against $\mathrm{Mg}$-number (all $\mathrm{Fe}$ as $\mathrm{Fe}^{2+}$ ) for anhydrous experiments at $0.7 \mathrm{GPa}$ (filled symbols, this study) and 1.0 GPa (open symbols, Villiger et al., 2004): (a) $\mathrm{Al}_{2} \mathrm{O}_{3}$; (b) $\mathrm{TiO}_{2}$; (c) $\mathrm{Na}_{2} \mathrm{O}$. Experimental cpx data from the literature (grey filled symbols): 1 bar data are from Grove \& Bryan (1983), Baker \& Eggler (1987), Tormey et al. (1987), Grove et al. (1990), Yang et al. (1996) and Sano et al. (2001); 0.2 GPa data from Tormey et al. (1987) and Grove et al. (1992); 0.8 GPa data from Baker \& Eggler (1987) and Grove et al. (1990, 1992); 1.0 GPa data from Bartels et al. (1991), Fram \& Longhi (1992) and Grove et al. (1992). Continuous lines indicate fractional crystallization trends at $0.7 \mathrm{GPa}$; the dasheddotted line represents the equilibrium crystallization trend at $0.7 \mathrm{GPa}$; long-dashed lines illustrate fractional crystallization trends at $1.0 \mathrm{GPa}$; the short-dashed line traces the equilibrium crystallization trend at $1.0 \mathrm{GPa}$. 


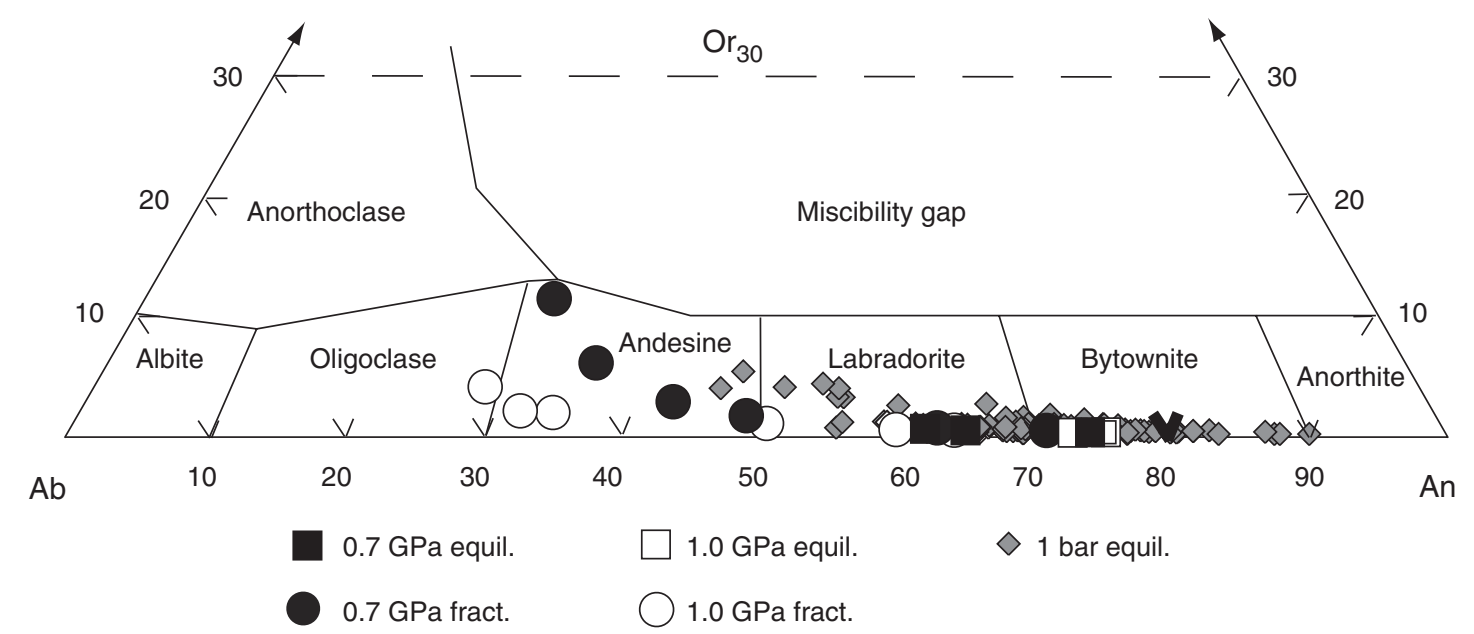

Fig. 7. Compositions of experimental plagioclase plotted as molar units in the albite-orthoclase-anorthite ternary. Plagioclase values for anhydrous fractional and equilibrium crystallization experiments at $0.7 \mathrm{GPa}$ (this study) and $1.0 \mathrm{GPa}$ experiments (Villiger et al., 2004) are plotted. Experimental plagioclase compositions from anhydrous experiments at 1 bar are given for comparison and are taken from Grove \& Bryan (1983), Baker \& Eggler (1987), Tormey et al. (1987), Grove et al. (1990), Yang et al. (1996) and Sano et al. (2001).

as the orthoclase component, increases with differentiation from 0.003 to $0 \cdot 11 X_{\mathrm{Or}}$, consistent with the strongly increasing $\mathrm{K}_{2} \mathrm{O}$ contents of the coexisting liquid phase (from 0.21 to $3.11 \mathrm{wt} \%$ ). Plagioclases from the equilibrium crystallization show restricted ranges in $X_{\mathrm{An}}$ and $X_{\mathrm{Or}}$, varying in the range $0.74-0.62$ and $0.002-0.003$, respectively.

\section{THE EFFEGT OF PRESSURE ON THE DIFFERENTIATION OF THOLEIITIG BASALTS Phase relations}

Only a limited number of experimental studies have constrained the phase equilibria of anhydrous basalts at pressures between 0.2 and 0.7 GPa (e.g. 0.2 GPa: Tormey et al., 1987; Grove et al., 1992; 0.4 GPa: Bender et al., 1978; 0.45 GPa: Green \& Ringwood, 1967; 0.5 GPa: Gust \& Perfit, 1987; 0.6 GPa: Bender et al., 1978). The 1 bar liquidus temperatures of these experiments vary between $1210^{\circ} \mathrm{C}$ and $1390^{\circ} \mathrm{G}$ depending on their bulk compositions. Olivine is the liquidus phase crystallizing at temperatures between $1207^{\circ} \mathrm{C}$ and $1380^{\circ} \mathrm{C}$. These experimental studies inferred an increase of the liquidus temperature by $40-50^{\circ} \mathrm{C}$ over a pressure interval of $1.0 \mathrm{GPa}$. The temperature of first appearance of plagioclase in the phase assemblages varies between $1170^{\circ} \mathrm{C}$ and $1270^{\circ} \mathrm{C}$ and increases in most of the studies by $35-45^{\circ} \mathrm{C}$ in the range 1 bar-1.0 GPa. Green \& Ringwood (1967), however, reported a negative slope of the plagioclase-in curve with an apparent temperature decrease of $50^{\circ} \mathrm{C}$ over $0.9 \mathrm{GPa}$. The saturation temperature of clinopyroxene varies between $1102^{\circ} \mathrm{C}$ and $1290^{\circ} \mathrm{C}$. Experiments at $1 \mathrm{bar}$ by Gust \& Perfit (1987) indicated that the cpx-in temperature is $f \mathrm{O}_{2}$ dependent: Cpx first crystallizes at $1102^{\circ} \mathrm{C}$ at an $\mathrm{fO}_{2}$ corresponding to QFM - 1 and at $1150^{\circ} \mathrm{C}$ under conditions corresponding to $\mathrm{NNO}+1.5$. The cpx-in temperature increases by $125^{-}-145^{\circ} \mathrm{C}$ from 1 bar to 1.0 GPa pressure. Green \& Ringwood (1967) reported a flatter slope of $50-70^{\circ} \mathrm{C}$ over $0.9 \mathrm{GPa}$. The flatter slope of the cpx-in curve in a pressure-temperature section relative to the ol-in and plg-in curves results in earlier crystallization of olivine and plagioclase at lower pressures with respect to cpx. The crossover of the cpx-in and plg-in curves is located between 0.5 and $0.8 \mathrm{GPa}$. Below these pressures ol + plg forms the high-temperature assemblage, producing dunitic and troctolitic cumulates. Experiments performed between 0.7 and $1.0 \mathrm{GPa}$ (Green \& Ringwood, 1967; Bender et al., 1978; Elthon \& Scarfe, 1984; Gust \& Perfit, 1987; Eggins, 1992; Grove et al., 1992; Kinzler \& Grove, 1992; Villiger et al., 2004) resulted in the crystallization of clinopyroxene at similar or higher temperatures than plagioclase. Consequently, the crystallization of a primitive tholeiitic magma at pressures in excess of $0.5-0.8 \mathrm{GPa}$ leads to the formation of cumulates composed of dunite followed by lherzolite, wehrlite and websterite, or directly by the crystallization of gabbroic or gabbronoritic cumulates.

\section{Liquid lines of descent}

To explore effects of pressure on the liquid lines of descent, data from equilibrium and fractional crystallization experiments at 1.0 GPa (Villiger et al., 2004), and 1 bar (Yang et al., 1996), plus the 1 bar and $1.0 \mathrm{GPa}$ phase boundaries from Grove \& Baker (1984), are plotted in addition to the experimental data at $0.7 \mathrm{GPa}$ (this study) in Fig. 4. At $1.0 \mathrm{GPa}$ the trend of projected liquids is 
dominated by early fractionation/crystallization of cpx, driving liquids to low normative cpx contents. At lower pressures, enhanced olivine stability shifts the liquid compositions in the first fractionation/crystallization steps away from the olivine apex of the $\mathrm{ol}^{-}{ }^{-} \mathrm{cpx}^{-} \mathrm{qtz}$ plane and leads to generally more cpx-rich liquids at a given normative qtz content. It is noteworthy that the effect of enhanced normative cpx content with decreasing pressure is much more pronounced for equilibrium than for fractional crystallization experiments. Attempts to model the liquid line of descent using the thermodynamic algorithms MELTS and pMELTS (Ghiorso \& Sack, 1995; Asimow \& Ghiorso, 1998; Ghiorso et al., 2002) produced liquid lines of descent that are dramatically different from the experimentally derived ones, but similar to the liquid lines of descent obtained from MELTS and pMELTS at 1.0 GPa. Villiger et al. (2004) have extensively discussed the comparison between experimentally derived and calculated liquid lines of descent for dry tholeiitic magmas at elevated pressures and the basic conclusions remain the same. Extensive crystallization of augitic and in more advanced stages of pigeonitic cpx drives the derivative liquids in Fig. 4 away from the cpx corner and ultimately into the nepheline-normative field, outside the triangle towards the lower-left side (opposite to qtz).

\section{Liquid compositions}

To evaluate the effect of pressure on the compositional evolution of experimental liquids with differentiation, major oxide compositions of experimental liquids at 1.0 GPa (Villiger et al., 2004) and equilibrium crystallization experiments between 1 bar and $1.0 \mathrm{GPa}$ from the literature (for references see caption of Fig. 5) have been plotted together with the $0.7 \mathrm{GPa}$ data from this study as a function of the degree of differentiation expressed as Mg-number in Fig. 5a-f. Silica (Fig. 5a) increases progressively with differentiation from basaltic to rhyodacitic compositions for fractional crystallization experiments at 1.0 GPa (Villiger et al., 2004), whereas at $0.7 \mathrm{GPa}$, early $\mathrm{SiO}_{2}$ enrichment is only observed for the equilibrium crystallization experiments. For fractional crystallization experiments at $0.7 \mathrm{GPa}, \mathrm{SiO}_{2}$ increases only moderately along the liquid line of descent until a late stage when ilmenite begins to crystallize. Liquid compositions in equilibrium crystallization experiments on various starting compositions at 1 bar, $0.2 \mathrm{GPa}, 0.8 \mathrm{GPa}$ and $1.0 \mathrm{GPa}$ generally have relatively low $\mathrm{SiO}_{2}$ contents (48-53 wt \%), except for two experiments at $0.8 \mathrm{GPa}$ on differentiated compositions that contain 57.1 and 57.8 wt \% $\mathrm{SiO}_{2}$ (AT-29: Baker \& Eggler, 1987).

$\mathrm{CaO}$ increases at all pressures when ol is the only liquidus phase. After the first appearance of plg at low pressures, $\mathrm{CaO}$ remains relatively constant (Fig. 5b).
The crystallization of cpx leads to a pronounced decrease in the $\mathrm{CaO}$ content. The expansion of the olivine stability field towards lower pressures results in systematically higher $\mathrm{CaO}$ maxima for low-pressure fractionation trends compared with higher pressure conditions. The slope of the $\mathrm{CaO}$ vs $\mathrm{Mg}$-number trend at $0.7 \mathrm{GPa}$ is slightly flatter than at $1.0 \mathrm{GPa}$, possibly because of the lower $\mathrm{CaO}$ contents of the crystalline phase assemblages at a given $\mathrm{Mg}$-number at 0.7 GPa compared with 1.0 GPa. The variation of $\mathrm{CaO}$ with increasing differentiation is clearly dependent on the pressure of crystallization as shown in an accompanying study (Villiger et al., 2006). The evolution of $\mathrm{Al}_{2} \mathrm{O}_{3}$ along anhydrous liquid lines of descent is dominated by the crystallization behaviour of plg: $\mathrm{Al}_{2} \mathrm{O}_{3}$ increases until first appearance of plg on the liquidus. At high pressures plagioclase appears later on the liquidus, resulting in systematically higher maxima in $\mathrm{Al}_{2} \mathrm{O}_{3}$ with increasing pressures. Lower $\mathrm{Al}$ contents of pyroxenes and lower $\mathrm{plg} / \mathrm{cpx}$ ratios in the crystalline solid assemblage at $0.7 \mathrm{GPa}$ are responsible for the flatter slope of $\mathrm{Al}_{2} \mathrm{O}_{3}$ with increasing differentiation with respect to the liquids at $1.0 \mathrm{GPa} . \mathrm{Al}_{2} \mathrm{O}_{3}$ contents of glasses produced at $1 \mathrm{bar}, 0.2 \mathrm{GPa}, 0.8 \mathrm{GPa}$ and 1.0 GPa using various starting compositions define variable $\mathrm{Al}_{2} \mathrm{O}_{3}$ trends depending on both pressure and the initial $\mathrm{Al}_{2} \mathrm{O}_{3}$ content.

The variation of $\mathrm{FeO}_{\text {tot }}$ in the fractional crystallization experiments exhibits strongly contrasting behaviour at 1.0 and $0.7 \mathrm{GPa}$. At $1.0 \mathrm{GPa}$ it reaches a maximum at $<10.0$ wt $\%$. $\mathrm{FeO}_{\text {tot }}$ starts to decrease when the sum of $\mathrm{FeO}$ in the solid phase assemblage exceeds the amount of $\mathrm{FeO}$ in the coexisting liquid (Villiger et al., 2004). At $0.7 \mathrm{GPa}, \mathrm{FeO}_{\text {tot }}$ reaches a maximum of 16.7 wt $\%$ and only slightly decreases in the last fractionation step when significant amounts of ilmenite crystallize. Except for the first (and last) fractionation step the calculated cumulate compositions do not exceed the FeO content of the coexisting liquids. Liquid compositions from equilibrium crystallization experiments taken from the literature at $1 \mathrm{bar}, 0 \cdot 2,0.8$ and $1.0 \mathrm{GPa}$ evolve along a trajectory of increasing $\mathrm{FeO}_{\text {tot }}$ with differentiation that is steeper than for either the fractional or equilibrium crystallization experiments at 0.7 and 1.0 GPa on composition HK19 (this study). The starting compositions of the former studies contain higher $\mathrm{FeO}_{\text {tot }}$ at a given $\mathrm{Mg}$-number than the starting composition (HK19) of our experiments. Two experimental glasses produced at $0.8 \mathrm{GPa}$ on differentiated compositions (AT-29: Baker \& Eggler, 1987) plot between the 1.0 GPa and $0.7 \mathrm{GPa}$ fractional crystallization experiments and four glasses at $0.2 \mathrm{GPa}$ (Tormey et al., 1987) plot near the fractional crystallization trends at $0.7 \mathrm{GPa}$.

$\mathrm{Na}_{2} \mathrm{O}$ becomes progressively enriched in the liquid phase with increasing differentiation for fractional and 
equilibrium crystallization experiments until the solid phase assemblage becomes more $\mathrm{Na}_{2} \mathrm{O}$-rich than the coexisting liquid, resulting in a slight to moderate decrease of the $\mathrm{Na}_{2} \mathrm{O}$ content in the last crystallization steps. Sodium contents in the melt reach higher values at $1.0 \mathrm{GPa}(4.28 \mathrm{wt} \%)$ than at $0.7 \mathrm{GPa}(3.65 \mathrm{wt} \%) . \mathrm{Na}_{2} \mathrm{O}$ contents of equilibrium crystallization experiments at 1 bar, $0.2 \mathrm{GPa}$ and $0.8 \mathrm{GPa}$ using different starting compositions scatter between 1.0 and $3.8 \mathrm{wt} \%$ at a $\mathrm{Mg}$-number of $0 \cdot 6$, clearly indicating that the $\mathrm{Na}_{2} \mathrm{O}$ content of the starting composition dominates the $\mathrm{Na}_{2} \mathrm{O}$ evolution in differentiated liquids. Experimental problems arising from $\mathrm{Na}$ loss during the experiments, which has been reported for some 1 bar experiments, as well as analytical difficulties caused by $\mathrm{Na}_{2} \mathrm{O}$ loss during electron microprobe analysis of Na-rich glasses pose additional problems for the interpretation of the $\mathrm{Na}_{2} \mathrm{O}$ vs $\mathrm{Mg}$-number evolution diagram.

$\mathrm{TiO}_{2}$ behaves as an incompatible element over most of the differentiation history: it increases moderately before plg crystallizes. The crystallization of the $\mathrm{TiO}_{2}$-free phase (plg) results in a more rapid increase of $\mathrm{TiO}_{2}$ in the melt phase of the fractional crystallization experiments until the onset of ilmenite crystallization. The maximum $\mathrm{TiO}_{2}$ content attained in the differentiation trend at $0.7 \mathrm{GPa}$ is considerably higher than at $1.0 \mathrm{GPa}$, most probably related to the earlier saturation of plg and the lower $\mathrm{TiO}_{2}$ contents of the pyroxenes. Equilibrium crystallization experiments with different bulk compositions at 1 bar, $0.2 \mathrm{GPa}, 0.8 \mathrm{GPa}$ and $1.0 \mathrm{GPa}$ follow different $\mathrm{TiO}_{2}$ trends controlled by their initial composition and phase relations.

\section{Glinopyroxene compositions}

The $\mathrm{Al}_{2} \mathrm{O}_{3}$ content of clinopyroxene (Fig. 6a) increases concomitantly with that of the liquid until plagioclase co-precipitates and decreases thereafter. It reaches higher maxima at $1.0 \mathrm{GPa}(6.2$ and $8.1 \mathrm{wt} \%$ for fractional and equilibrium crystallization, respectively) than at $0.7 \mathrm{GPa}$, where cpx attains 4.3 and $5.1 \mathrm{wt} \% \mathrm{Al}_{2} \mathrm{O}_{3}$ for fractional and equilibrium crystallization experiments. Cpx from equilibrium crystallization experiments at 1 bar, $0.2 \mathrm{GPa}, 0.8 \mathrm{GPa}$ and $1.0 \mathrm{GPa}$ on different bulk compositions taken from the literature show variable $\mathrm{Al}_{2} \mathrm{O}_{3}$ trends, mainly correlating with pressure ( $\mathrm{plg}_{\mathrm{in}}{ }^{-}$ temperature) and the $\mathrm{Al}_{2} \mathrm{O}_{3}$ content of their coexisting liquids.

$\mathrm{TiO}_{2}$ contents of cpx increase for both fractional and equilibrium crystallization experiments at 1.0 and $0.7 \mathrm{GPa}$ with increasing differentiation (Fig. 6b). Only in the last steps of the fractionation experiments at both 0.7 and $1.0 \mathrm{GPa}$ is a marked decrease of the $\mathrm{TiO}_{2}$ concentrations in cpx observed. This coincides with the onset of ilmenite crystallization. Despite the lower $\mathrm{TiO}_{2}$ contents in the coexisting liquids, the $\mathrm{TiO}_{2}$ content of cpx at
1.0 GPa reaches higher values of up to $1.3 \mathrm{wt} \%$ compared with cpx at $0.7 \mathrm{GPa}(1.0 \mathrm{wt} \%)$. Consequently, this results in higher Ti partition coefficients between pyroxene and coexisting melts at $1.0 \mathrm{GPa}$ than at $0.7 \mathrm{GPa}$ (see next section). The $\mathrm{TiO}_{2}$ contents of cpx in equilibrium crystallization experiments at 1 bar, $0.2 \mathrm{GPa}, 0.8 \mathrm{GPa}$ and $1.0 \mathrm{GPa}$ (reported in the literature) that were conducted on variable starting compositions show different amounts of $\mathrm{TiO}_{2}$ predominantly depending on the bulk composition of the starting material.

The $\mathrm{Na}_{2} \mathrm{O}$ contents of cpx evolve similarly for fractional and equilibrium crystallization experiments, reaching maximum concentrations at the onset of plg crystallization (Fig. 6c). Cpx from experiments performed at $1.0 \mathrm{GPa}$ contains higher concentrations of $\mathrm{Na}_{2} \mathrm{O}$ at a comparable $\mathrm{Mg}$-number than cpx at $0.7 \mathrm{GPa}$, reflecting the increasing jadeite $\left(\mathrm{NaAlSi}_{2} \mathrm{O}_{6}\right)$ component with increasing pressure. Literature data on cpx from experiments at 1 bar, $0.2 \mathrm{GPa}, 0.8 \mathrm{GPa}$ and $1.0 \mathrm{GPa}$ support the general observation that the $\mathrm{Na}_{2} \mathrm{O}$ contents of cpx are higher for higher pressure experiments. Different trends at identical pressures suggest that the $\mathrm{Na}_{2} \mathrm{O}$ contents of the cpx are also dependent on the bulk composition of the starting material.

\section{Plagioclase compositions}

Plagioclase compositions from the 0.7 and $1.0 \mathrm{GPa}$ experiments are plotted together with 1 bar data (data sources given in caption of Fig. 7) in a molar albiteorthoclase-anorthite diagram in Fig. 7. Plagioclase compositions vary between $\mathrm{An}_{75}$ and $\mathrm{An}_{29}$ for the highpressure experiments and reach $\mathrm{An}_{90}$ for the $1 \mathrm{bar}$ experiments. In the fractional crystallization experiments, we observed a significant increase in the Or component with decreasing pressure for highly differentiated compositions. Increased $\mathrm{K}_{2} \mathrm{O}$ contents, exceeding the values for the 0.7 and $1.0 \mathrm{GPa}$ data, are also observed for intermediate plagioclase compositions at 1 bar, indicating a general trend of increasing $\mathrm{K}_{2} \mathrm{O}$ contents with decreasing pressure.

\section{Mineral-liquid exchange reactions Clinopyroxene}

The partition coefficients for $\mathrm{Al}_{2} \mathrm{O}_{3}, \mathrm{TiO}_{2}$ and $\mathrm{Na}_{2} \mathrm{O}$ between clinopyroxene and coexisting liquid are listed in Table 4. Figure $8 \mathrm{a}^{-} \mathrm{c}$ displays the logarithms of the clinopyroxene-liquid distribution coefficients for these oxides $\left(\log \mathrm{Al}_{2} \mathrm{O}_{3} K_{\mathrm{d}}=\log \left[\mathrm{Al}_{2} \mathrm{O}_{3}\right.\right.$ (pyx)/ $/ \mathrm{Al}_{2} \mathrm{O}_{3}$ (liq) $]$ ) as functions of the inverse temperature $(\mathrm{K})$ and their calculated activities in the melt phase.

Logarithms of $\mathrm{Al}_{2} \mathrm{O}_{3}$ partition coefficients at $0.7 \mathrm{GPa}$ decrease with decreasing temperature after the onset of plagioclase crystallization from -0.55 to -0.87 . The Al $K_{\mathrm{d}}$ values of fractional and equilibrium crystallization experiments at $0.7 \mathrm{GPa}$ follow a trend similar to that observed 

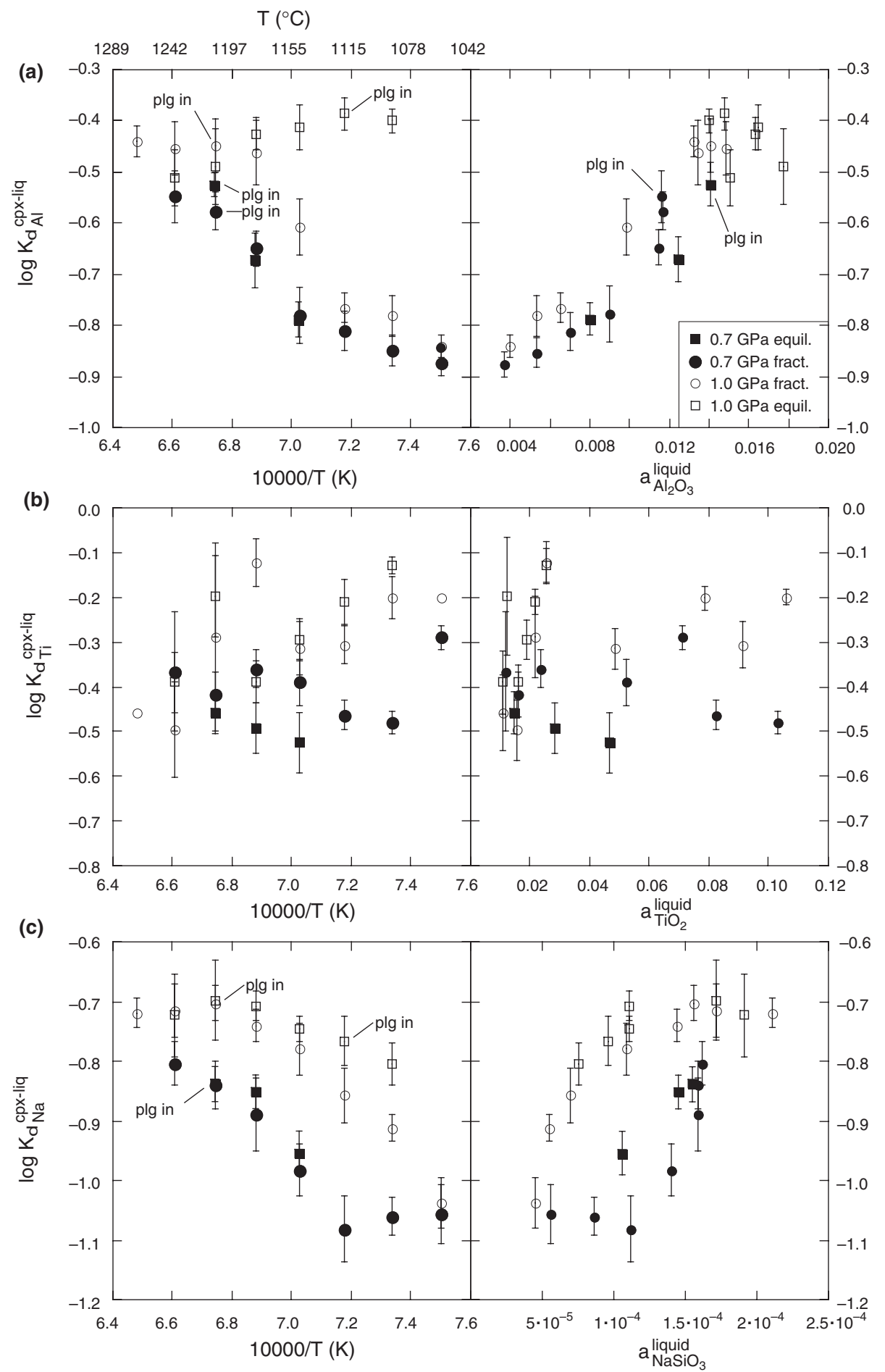

Fig. 8. Logarithm of (a) $\mathrm{Al}_{2} \mathrm{O}_{3}$, (b) $\mathrm{TiO}_{2}$ and (c) $\mathrm{Na}_{2} \mathrm{O}$ partition coefficients (log $K_{\mathrm{d}}$ ) between clinopyroxene and liquid as functions of reciprocal temperature $\left(\mathrm{K}^{-1}\right)$ and calculated $\mathrm{Al}_{2} \mathrm{O}_{3}(\mathrm{a}), \mathrm{TiO}_{2}(\mathrm{~b})$ and $\mathrm{NaSiO}_{3}(\mathrm{c})$ activities in the liquid phase for equilibrium and fractional crystallization experiments at $1.0 \mathrm{GPa}$ (Villiger et al., 2004) and $0.7 \mathrm{GPa}$ pressure (this study). The activities of components in the melt phase were calculated for each experimental glass composition using the MELTS Supplemental Calculator (Ghiorso \& Sack, 1995; Asimow \& Ghiorso, 1998) at $0.7 \mathrm{GPa}$ and $1.0 \mathrm{GPa}$ and their respective experimental temperatures $\left(1330-1060^{\circ} \mathrm{C}\right)$. 


\section{\begin{tabular}{l|l|l|l} 
JOURNAL OF PETROLOGY & VOLUME 48 & NUMBER 1 & JANUARY 2007
\end{tabular}}

for the fractional crystallization experiments at $1.0 \mathrm{GPa}$ $(-0.44$ to -0.84$)$, but displaced to lower values, unlike the $1.0 \mathrm{GPa}$ equilibrium crystallization experiments where $\mathrm{Al} K_{\mathrm{d}}$ increases with differentiation as a result of the delayed crystallization of plagioclase (Villiger et al., 2004). The possible dependence of the $\mathrm{Al}$ partitioning behaviour on the liquid composition was tested by calculating the $\mathrm{Al}_{2} \mathrm{O}_{3}$ and $\mathrm{SiO}_{2}$ activities of the liquids with the supplemental calculator provided on the MELTS web page of Mark Ghiorso (http://CTserver.uchicago.edu) at the pressure-temperature conditions of the experiments. The calculated $\mathrm{Al}_{2} \mathrm{O}_{3}$ activities are plotted in Fig. 8a as a function of $\log \mathrm{Al} K_{\mathrm{d}}$. A clear positive correlation exists between the $\mathrm{Al}_{2} \mathrm{O}_{3}$ pyroxene-liquid $K_{\mathrm{d}}$ and the calculated $\mathrm{Al}_{2} \mathrm{O}_{3}$ activities of the liquid phases of fractional and equilibrium crystallization experiments at $0.7 \mathrm{GPa}$ as observed by Villiger et al. (2004) for 1.0 GPa. These observations reinforce previous statements that the partitioning of $\mathrm{Al}_{2} \mathrm{O}_{3}$ between coexisting liquid and pyroxene is strongly controlled by the thermodynamic properties of the liquid phase (Villiger et al., 2004). The complementary behaviour of the variation of $\log K_{\mathrm{d}}$ with the calculated alumina and silica activities (not shown) of the liquid phase is consistent with a control by the Tschermak's component in cpx $\left(\mathrm{Fe}^{2+}, \mathrm{Mg}\right.$ or $\mathrm{CaAl}_{2} \mathrm{SiO}_{6}$ component in cpx) and by the activity of the Tschermak's component in the liquid phase, which in turn is related to the variable onset of plagioclase crystallization at 0.7 and $1.0 \mathrm{GPa}$ in the fractional and equilibrium crystallization experiments.

The $\mathrm{TiO}_{2}$ distribution coefficients (log $K_{\mathrm{d}}$ pyx-liq) plotted against the reciprocal temperature and calculated $\mathrm{TiO}_{2}$ activities in the liquid phase scatter between -0.29 and -0.48 for fractional and -0.46 and -0.52 for equilibrium crystallization experiments (Fig. 8b). The average $\log K_{\mathrm{d}}$ values for fractional $(-0.12$ to -0.50$)$ and equilibrium crystallization experiments ( -0.13 to -0.39 ) are higher at 1.0 than at $0.7 \mathrm{GPa}$. We did not observe any systematic correlation with either the temperature or $\mathrm{Ti}$ activity of the coexisting liquid phases. $\mathrm{Ti}$ incorporation in pyroxene is mainly controlled by crystal chemical parameters and is often taken as an analogue for the behaviour of high field strength elements (HFSE; Kelemen et al., 1990; Forsythe et al., 1994). $\mathrm{TiO}_{2}$ contents generally correlate positively with $\mathrm{Al}^{\mathrm{IV}}$ in cpx (Lundstrom et al., 1998; Hill et al., 2000; Wood \& Trigila, 2001) and $\mathrm{Ti}$ is incorporated as the $\mathrm{CaTiAl}_{2} \mathrm{O}_{6}$ molecule (Onuma \& Yagi, 1971; Akella \& Boyd, 1972) through a coupled substitution $\mathrm{Ti}^{4+[\mathrm{VI}]}+2 \mathrm{Al}^{[\mathrm{IV}]}=$ $\mathrm{R}^{2+[\mathrm{VI}]}+2 \mathrm{Si}^{[\mathrm{IV}]}$ (Verhoogen, 1962). Figure 9a shows that the $\log K_{\mathrm{d}}$ values of $\mathrm{TiO}_{2}$ between cpx and liquid roughly correlate with the $\mathrm{SiO}_{2} / \mathrm{Al}_{2} \mathrm{O}_{3}$ ratios of the liquids at $0.7 \mathrm{GPa}$ (this study) and 1.0 GPa (Villiger et al., 2004) and the anhydrous experiments between 1 bar and 1.0 GPa
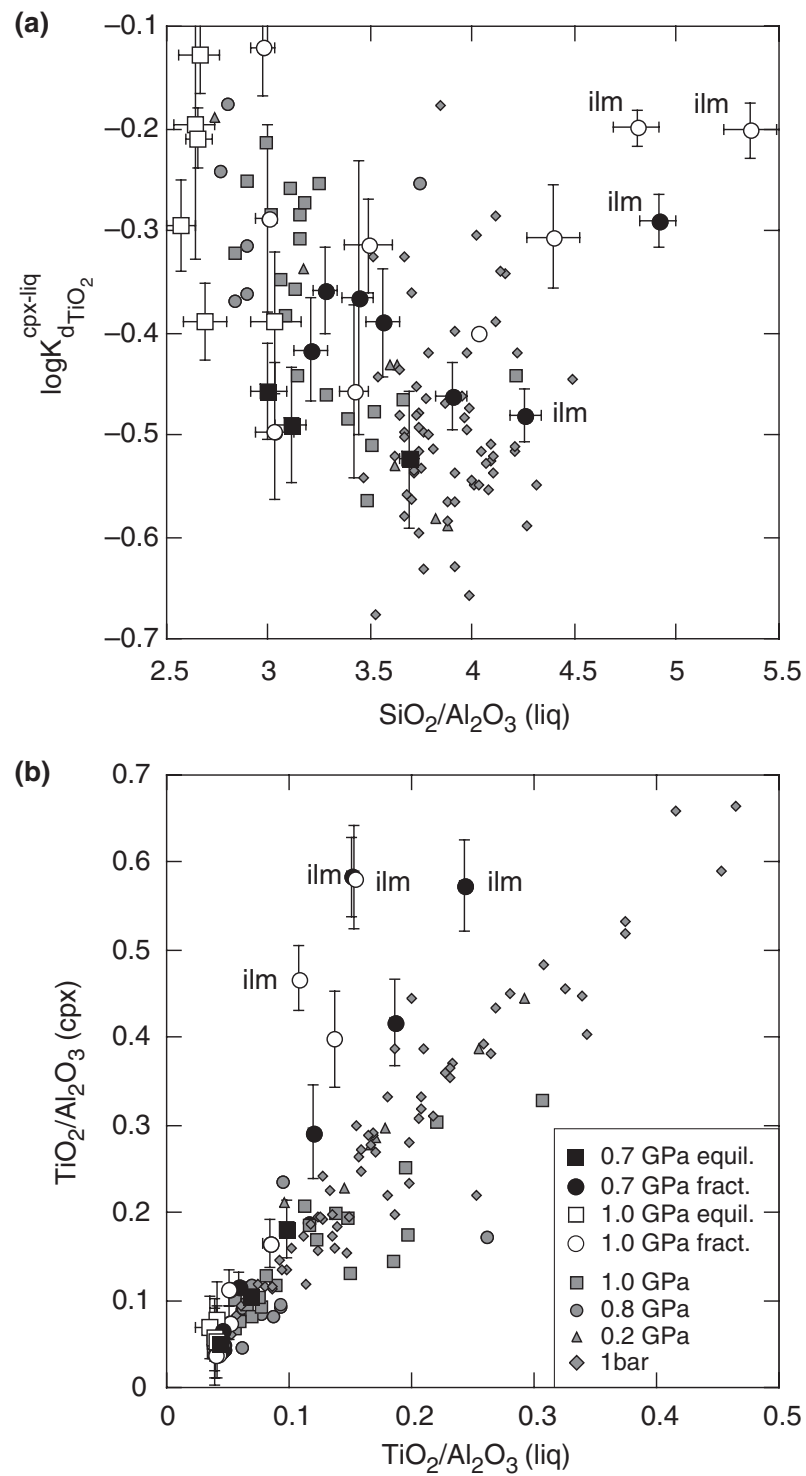

Fig. 9. (a) Logarithm of the $\mathrm{TiO}_{2}$ partition coefficients $\left(\log K_{\mathrm{d}}\right)$ between clinopyroxene and liquid as a function of the $\mathrm{SiO}_{2} / \mathrm{Al}_{2} \mathrm{O}_{3}$ ratio of the liquid; (b) $\mathrm{TiO}_{2} / \mathrm{Al}_{2} \mathrm{O}_{3}$ ratios of clinopyroxene as a function of the $\mathrm{TiO}_{2} / \mathrm{Al}_{2} \mathrm{O}_{3}$ ratio of coexisting liquids. Data for equilibrium and fractional crystallization experiments at $1.0 \mathrm{GPa}$ (Villiger et al., 2004) and at $0.7 \mathrm{GPa}$ (this study) are plotted. Data sources for anhydrous equilibrium crystallization experiments at 1 bar, $0.2 \mathrm{GPa}, 0.8 \mathrm{GPa}$ and $1.0 \mathrm{GPa}$ are as in Fig. 6 .

(data sources are given in the caption of Fig. 6). The most differentiated $\mathrm{cpx}^{-}$-glass pairs in the fractional crystallization experiments at $0.7 \mathrm{GPa}$ and $1.0 \mathrm{GPa}$ display an inversion of the overall negative correlation with the $\mathrm{SiO}_{2} /$ $\mathrm{Al}_{2} \mathrm{O}_{3}$ ratio. The solid assemblages in these experiments contain ilmenite (Fig. 9a). Figure 9b illustrates the variation of $\mathrm{TiO}_{2} / \mathrm{Al}_{2} \mathrm{O}_{3}$ ratios in cpx as a function of the $\mathrm{TiO}_{2} /$ $\mathrm{Al}_{2} \mathrm{O}_{3}$ ratios of coexisting liquids. A nearly linear positive trend is observed for most experiments, with the exception 
of the fractional crystallization experiments at $0.7 \mathrm{GPa}$ and $1.0 \mathrm{GPa}$ that define a steeper trend than the equilibrium crystallization experiments from the literature. This deviation from the general trend most probably reflects the higher $\mathrm{Al}_{2} \mathrm{O}_{3}$ contents of the glasses (lower $\mathrm{TiO}_{2} / \mathrm{Al}_{2} \mathrm{O}_{3}$ ) produced by fractional crystallization at similar $\mathrm{Mg}$-number compared with equilibrium crystallization experiments. The dependence of the pyroxene $\mathrm{Ti}$ solubility on the $\mathrm{Al}_{2} \mathrm{O}_{3}$ content of coexisting liquids has been reported by Thompson (1974) and Forsythe et al. (1994).

The $\mathrm{Na}$ distribution coefficients of the fractional crystallization experiments at $0.7 \mathrm{GPa}$ (Fig. 8c) decrease with decreasing temperature and decreasing $\mathrm{NaSiO}_{3}$ activities in the liquid from -0.80 to $-1 \cdot 08$, except for the last two steps of fractionation where a slight increase to -1.06 is observed; this occurs despite a continuous decrease of the sodium concentrations in clinopyroxene. The log $\mathrm{Na}-K_{\mathrm{d}}$ of equilibrium crystallization experiments follows a similar trend decreasing from -0.84 to -0.96 . At $1.0 \mathrm{GPa}$, an initial increase from -0.72 to -0.70 is followed by continuous decrease of the $\log \mathrm{Na}-K_{\mathrm{d}}$ pyx-liq to -0.80 in equilibrium and with a steeper slope for the fractional crystallization experiments to $-1 \cdot 04 . \log \mathrm{Na}-K_{\mathrm{d}}$ as a function of $\mathrm{NaSiO}_{3}$ activity decreases for both series at $1.0 \mathrm{GPa}$ after the onset of plg crystallization. The shift of the $\mathrm{Na}-K_{\mathrm{d}}$ to higher values at $1.0 \mathrm{GPa}$ compared with 0.7 for a given $\mathrm{NaSiO}_{3}$ activity in the liquid indicates that increasing jadeite $\left(\mathrm{NaAlSi}_{2} \mathrm{O}_{6}\right)$ component of cpx as a function of pressure is an important parameter controlling the $\mathrm{Na}_{2} \mathrm{O}$ content of the cpx in our experiments.

Figure 10a displays the average values of experimental

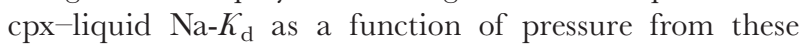
experiments combined with a large number of literature data (references are given in the captions of Fig. 10). The Na- $K_{\mathrm{d}}$ values obtained from piston cylinder experiments conducted in graphite-platinum capsules range from 0.06 at $0.5 \mathrm{GPa}$ to 0.86 at $3.0 \mathrm{GPa}$. The data have been fitted by an exponential function shown as a continuous curve in Fig. 10a and given as the equation

$$
K_{\mathrm{dNa}}^{\mathrm{cpx}-\mathrm{liq}}=0 \cdot 063852 \times \exp [0 \cdot 85036 \times P(\mathrm{GPa})] .
$$

The average $K_{\mathrm{d}}$ observed at 1 bar and $0.2 \mathrm{GPa}$ is 0.09 . The 1 bar experiments were performed in gas mixing furnaces at $\mathrm{fO}_{2}$ corresponding to the FMQ or NNO equilibria. The $0.2 \mathrm{GPa}$ experiments were performed in internally heated hydrothermal apparatus using $\mathrm{Pt}_{90}-\mathrm{Fe}_{10}$ capsules assuming $f \mathrm{O}_{2}$ close the FMQ buffer. Toplis et al. (1994) investigated the effect of $f \mathrm{O}_{2}$ on the Na partitioning between clinopyroxene and liquid. The $\mathrm{Na}-K_{\mathrm{d}}$ values show an increase at $f \mathrm{O}_{2}$ conditions higher than FMQ related to the incorporation of $\mathrm{Na}$ as an acmite $\left(\mathrm{NaFe}^{3+} \mathrm{Si}_{2} \mathrm{O}_{6}\right)$ component in addition to the jadeite

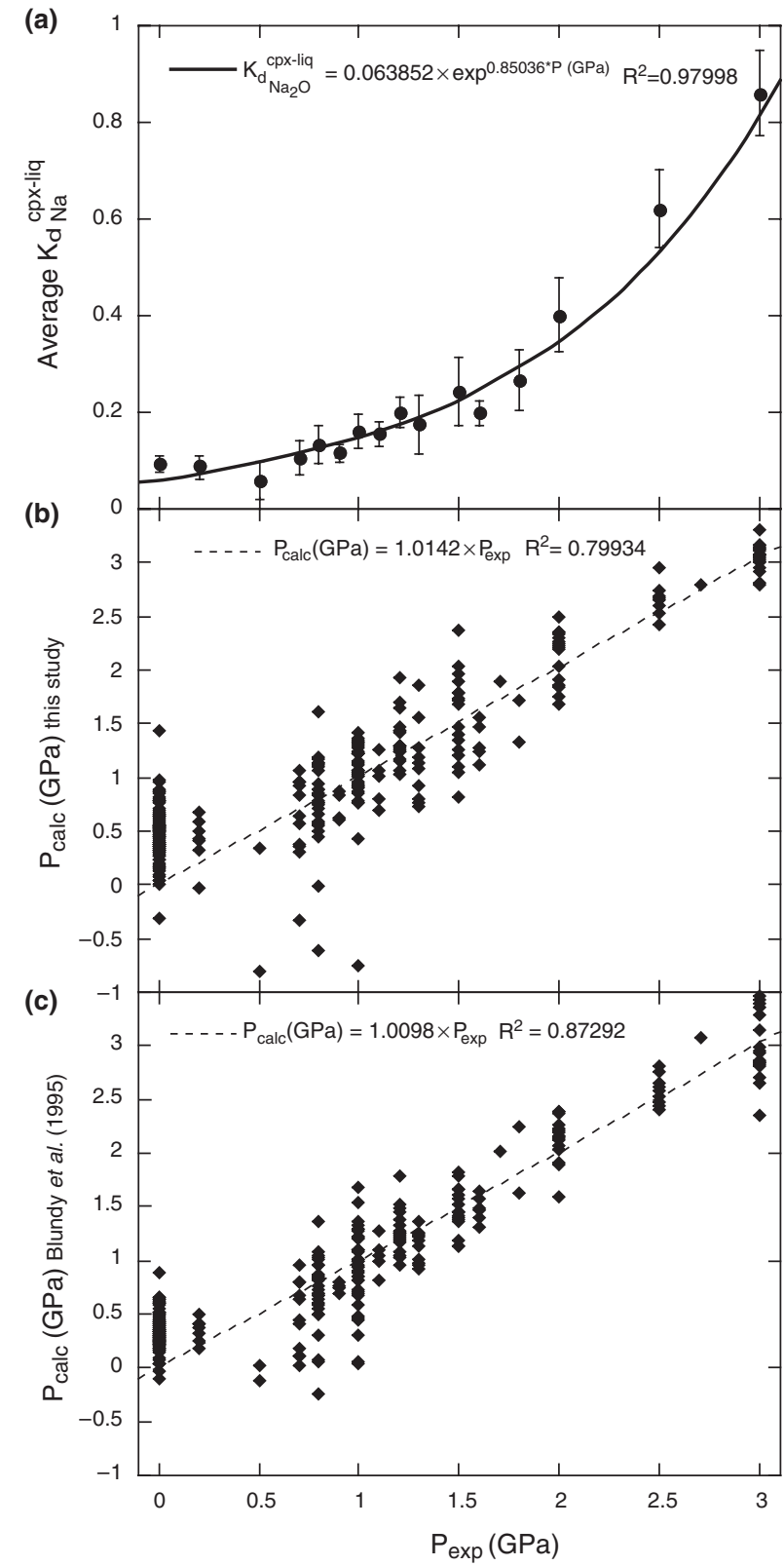

Fig. 10. (a) Average cpx-liquid $K_{d}$ for $\mathrm{Na}_{2} \mathrm{O}$ vs experimental pressure $(\mathrm{GPa})$; (b) pressures calculated with equation (2) plotted against experimental pressures (GPa); (c) pressures calculated with equation (4) (Blundy et al, 1995) plotted against experimental pressure $(\mathrm{GPa})$. Data for anhydrous experiments in the pressure range between 1 bar and $3.0 \mathrm{GPa}$ are taken from Bender et al. (1978), Grove \& Bryan (1983), Elthon \& Scarfe (1984), Baker \& Eggler (1987), Tormey et al. (1987), Grove et al. (1990, 1992), Bartels et al. (1991), Fram \& Longhi (1992), Kinzler \& Grove (1992), Baker et al. (1994), Panjasawatwong et al. (1995), Putirka et al. (1996), Yang et al. (1996), Johnson (1998), Thy et al. (1999), Sano et al. (2001), Pertermann \& Hirschmann (2003), Villiger et al. (2004) and this study. Error bars (Fig. 10a) indicate standard deviations at a given pressure. The lines represent fitted curves using exponential (a), and linear (b) and (c) functions, respectively. 
component $\left(\mathrm{NaAlSi}_{2} \mathrm{O}_{6}\right)$ that dominates at low $f \mathrm{O}_{2}$ conditions. Na loss is reported for most of the 1 bar experiments; this could also influence the $\mathrm{Na}$ partitioning provided the $\mathrm{Na}$ loss occurred preferentially from the liquid phase during late stages of the experiments.

Equation (1) has been rearranged to obtain the equation

$$
P(\mathrm{GPa})=\frac{\ln K_{\mathrm{dNa}}^{\mathrm{cpx}-\mathrm{liq}}}{0 \cdot 85036}+3 \cdot 2353208
$$

that was used to calculate pressures from $\mathrm{cpx}^{-}$-liquid $\mathrm{Na}$ partition coefficients. Figure 10b shows calculated vs experimental pressures. Blundy et al. (1995) have discussed the pressure and temperature dependence of $\mathrm{Na}$ partitioning between melt and clinopyroxene. Based on the jadeite melting reaction, their empirical formulation of the Na partitioning between cpx and liquid,

$$
\begin{aligned}
K_{\mathrm{dNa}}^{\mathrm{cpx}-\mathrm{liq}}= & \exp \left(\frac{10367+2100 \times P-165 \times P^{2}}{\mathcal{T}}\right. \\
& \left.-10 \cdot 27+0 \cdot 358 \times P-0 \cdot 0184 \times P^{2}\right)
\end{aligned}
$$

exhibits increasing $K_{\mathrm{d}}$ with increasing pressure, but also decreasing $K_{\mathrm{d}}$ with increasing temperature. For comparison, equation (3) was solved for pressure (GPa) and the solution, than at $1.0 \mathrm{GPa}$ (see Fig. 7). Therefore, we have used the $\mathrm{CaO} /\left(\mathrm{Na}_{2} \mathrm{O}+\mathrm{K}_{2} \mathrm{O}\right)$ ratio (expressed in wt \%) between plagioclase and liquid in Fig. 11 instead of the $\mathrm{CaO} / \mathrm{Na}_{2} \mathrm{O}$ ratio used by Villiger et al. (2004). The positive correlation of the $\mathrm{CaO} / \mathrm{Na}_{2} \mathrm{O}$ ratio at constant $\mathrm{H}_{2} \mathrm{O}$ demonstrated experimentally by Sisson \& Grove (1993) and Berndt et al. (2005) is also valid for $\mathrm{CaO} /\left(\mathrm{Na}_{2} \mathrm{O}+\mathrm{K}_{2} \mathrm{O}\right)$ ratios but at slightly different values. Sisson \& Grove (1993) reported increasing $K_{\mathrm{d}}\left[=\left(\mathrm{CaO} / \mathrm{Na}_{2} \mathrm{O}\right)_{\mathrm{plg}} /\left(\mathrm{CaO} / \mathrm{Na}_{2} \mathrm{O}\right)_{\text {liq }}\right]$ with increasing $\mathrm{H}_{2} \mathrm{O}$ content in the melt phase. The $\mathrm{CaO} /\left(\mathrm{Na}_{2} \mathrm{O}+\mathrm{K}_{2} \mathrm{O}\right)$ of plagioclase plotted against the $\mathrm{CaO} /\left(\mathrm{Na}_{2} \mathrm{O}+\mathrm{K}_{2} \mathrm{O}\right)$ of the liquids of the equilibrium and fractional crystallization experiments at $0.7 \mathrm{GPa}$ defines a linear function with a slope similar to the fractional crystallization experiments at $1.0 \mathrm{GPa}$ (Fig. 10). The slope defines an average $\mathrm{CaO} /\left(\mathrm{Na}_{2} \mathrm{O}+\mathrm{K}_{2} \mathrm{O}\right) K_{\mathrm{d}}$ between plg and melt of $0.94 \pm 0.08$ for fractional crystallization experiments at $0.7 \mathrm{GPa}$ and $1.05 \pm 0.14$ at $1.0 \mathrm{GPa}$. The average $K_{\mathrm{d}}$ of the equilibrium crystallization experiments at $0.7 \mathrm{GPa}$ is $1.00 \pm 0.09$ and $1.83 \pm 0.04$ at $1.0 \mathrm{GPa}$. Our data fall within the range of $K_{\mathrm{d}}$ of 226 nominally anhydrous experiments taken from the literature that cover the pressure range from 1 bar to $1.5 \mathrm{GPa}$. The total variation of all the experimental data is from 0.67 to 2.36 with an average value of $1.19 \pm 0 \cdot 30$ (references for experiments

$$
\begin{aligned}
P_{1 / 2}= & \frac{2100+0 \cdot 358 \times T}{-165-0 \cdot 0184 \times T} \\
& \pm \sqrt{\frac{[(2100+0 \cdot 358 \times T) /(-165-0 \cdot 0184 \times T)]^{2}}{4}-\frac{10367+T \times\left(-10 \cdot 27-\ln K_{\mathrm{d} \mathrm{Na}}^{\mathrm{cpx}-\mathrm{liq}}\right)}{-165-0 \cdot 0184 \times T}}
\end{aligned}
$$

was used to calculate pressures that are compared in Fig. 10c with the experimental pressures. There is no fundamental improvement by incorporating temperature as an additional variable to pressure (Fig. 10b compared with 10c). Therefore, we conclude that with the currently available dataset, a clear relationship between $\mathrm{Na}$ partitioning and temperature cannot be established. Our experimental dataset covers a large range of compositions and most probably implies that, in addition to the strong pressure dependence, a compositional effect and an effect depending on the phase assemblage coexisting with cpx and melt cannot be ruled out and is potentially more important than the inferred temperature dependence.

\section{Plagioclase}

Potassium becomes a much more important component in feldspars under fractional crystallization at $0.7 \mathrm{GPa}$ are given the caption of Fig. 11). In contrast to Fram \& Longhi (1992), Grove et al. (1992), Sisson \& Grove (1993) and Panjasawatwong et al. (1995), who invoked either negative or positive correlation of the plg-liq $K_{\mathrm{d}}$ with pressure, the dataset we have used here (Fig. 11) does not show any systematic pressure or temperature correlation over the range $0-1.5 \mathrm{GPa}$ and $1050-1300^{\circ} \mathrm{C}$.

\section{DISGUSSION AND GONGLUSIONS}

The results of this experimental study, performed at $0.7 \mathrm{GPa}$ and $1060-1270^{\circ} \mathrm{C}$, provide constraints on phase equilibria and the compositions of liquids and residual solids along the liquid lines of descent of anhydrous, mantle-derived primary magmas. The two contrasting series of experiments, simulating equilibrium (closed-system) and fractional (open-system) crystallization result in contrasting evolutionary trends. Liquids 


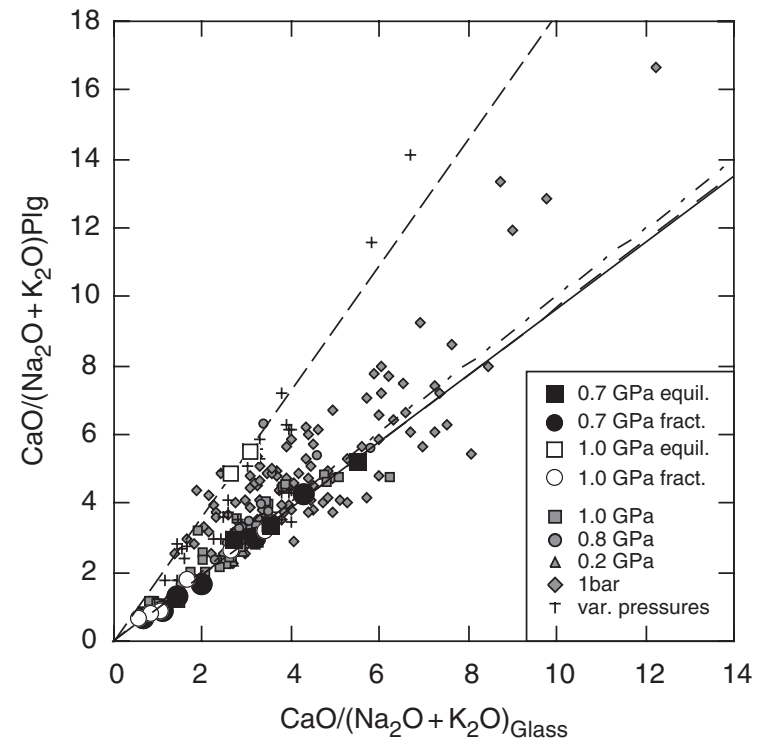

Fig. 11. $\mathrm{CaO} /\left(\mathrm{Na}_{2} \mathrm{O}+\mathrm{K}_{2} \mathrm{O}\right)$ (wt \%) of plagioclase vs that of coexisting liquid (quenched glass) in equilibrium and fractional crystallization experiments at $0.7 \mathrm{GPa}$ and at $1.0 \mathrm{GPa}$ (this study; Villiger et al., 2004). Experimental data are taken from the literature: 1 bar data are from Bender et al. (1978), Grove \& Bryan (1983), Tormey et al. (1987), Grove et al. (1990), Bartels et al. (1991), Baker et al. (1994), Yang et al. (1996), Thy et al. (1999) and Sano et al. (2001); 0.2 GPa data from Grove et al. (1992); 0.8 GPa data from Bender et al. (1978), Baker \& Eggler (1987) and Grove et al. (1990, 1992); 1.0 GPa data from Bartels et al. (1991), Grove et al. (1992) and Panjasawatwong et al. (1995). Crosses represent additional data taken from anhydrous experiments at $0.5 \mathrm{GPa}$ (Panjasawatwong et al. 1995); at $0.9 \mathrm{GPa}$ and $1.3 \mathrm{GPa}$ (Kinzler \& Grove (1992); and at $1.1 \mathrm{GPa}, 1.2 \mathrm{GPa}$ and $1.5 \mathrm{GPa}$ (Bartels et al., 1991).

in the fractional crystallization experiments evolve similarly to those of typical tholeiitic magma series: a moderate silica increase from basalt to basaltic andesite, paired with a strong $\mathrm{Fe}$ enrichment, followed by very late-stage $\mathrm{SiO}_{2}$ enrichment related to the extraction of ilmenite. In contrast, liquids in the equilibrium crystallization experiments at $0.7 \mathrm{GPa}$, as well as in all experiments at 1.0 GPa (Villiger et al., 2004), evolve more like calc-alkaline series magmas, with progressive $\mathrm{SiO}_{2}$ enrichment and only moderate Fe enrichment. The latter, however, is related to closed-system behaviour in the equilibrium crystallization experiments that limits any Fe enrichment to $\mathrm{Mg}$-number $>0 \cdot 5$. The change of $\mathrm{Al}_{2} \mathrm{O}_{3}$ and $\mathrm{CaO}$ concentrations along the liquid lines of descent is clearly related to pressure. Principal phase equilibria controls are responsible for their contrasting trends. Earlier plagioclase saturation in the experiments at $0.7 \mathrm{GPa}$ compared with the experiments at $1.0 \mathrm{GPa}$ results in lower $\mathrm{Al}_{2} \mathrm{O}_{3}$ contents of the liquids produced at $0.7 \mathrm{GPa}$. The expansion of the olivine stability field relative to cpx at lower pressures results in a higher $\mathrm{CaO}$ maximum on the liquid line of descent. In contrast to tholeiitic differentiation trends at low pressure (1 bar), suppressed plagioclase crystallization and the persistence of spinel crystallization cause continuous silica enrichment at $1.0 \mathrm{GPa}$ and in the equilibrium crystallization experiments at $0.7 \mathrm{GPa}$ with increasing differentiation. As a consequence, crystallization processes operating in the lower continental crust or even within the uppermost mantle below mid-ocean ridges (0.7-1.0 GPa pressure, equivalent to $\sim 20-35 \mathrm{~km}$ depth) lead to the production of large volumes of ultramafic cumulates, 4-28 wt \% at $0.7 \mathrm{GPa}$, consisting of dunites, wehrlites and plg-bearing websterites followed by gabbroic assemblages (gabbronorites and/or gabbros). The main difference from the experiments at $1.0 \mathrm{GPa}$ that produce $34-47 \mathrm{wt} \%$ of ultramafic cumulates is the absence of spinel websterites at $0.7 \mathrm{GPa}$ that form prior to gabbroic assemblages at $1.0 \mathrm{GPa}$.

Figure 12 displays the results (reported in Table 5) of empirical calculations of the density of the liquids coexisting with solid phases at each temperature and pressure in the equilibrium and fractional crystallization experiments, computed using the algorithms of Lange \& Carmichael (1987) and Lange (1994) for anhydrous conditions and for an initial $\mathrm{H}_{2} \mathrm{O}$ content of $1000 \mathrm{ppm}$ in the primary liquid (HK\# 19). To assess the probability that primary and differentiated liquids and/or magmas ascend from lower crustal reservoirs, the density contrasts with their surrounding wall-rocks, as well as the density contrast with the lithologies forming the middle and upper crust are important rheological parameters provided that the overall tectonic regime is extensional as is often the case when tholeiitic melts are formed through decompression of asthenospheric mantle. For comparison, densities of typical lower to middle crustal lithologies are also shown (Fig. 12). For felsic to intermediate crustal rocks average modal granite, granodiorite and tonalite compositions were taken from the Adamello batholith (Bianchi et al., 1970) and for mafic and pelitic crustal rocks modal abundances for hornblende and pyroxene gabbros and granulites and garnet-feldspar-biotite-sillimanite metapelites were taken from the Ivrea Zone (Schmid \& Wood, 1976). Densities were calculated at conditions of $0.7 \mathrm{GPa}$, $650^{\circ} \mathrm{C}$ and $1.0 \mathrm{GPa}, 800^{\circ} \mathrm{C}$ using the algorithm provided by Hacker \& Abers (2004). Felsic igneous rocks (granites or granodiorites) have densities of $2.69-2.72 \mathrm{~g} / \mathrm{cm}^{3}$, intermediate rocks (tonalites) $2.83 \mathrm{~g} / \mathrm{cm}^{3}$, amphibole gabbros and amphibolite-facies metapelites range from 2.92 to 2.97 , and pyroxeneol-gabbros and granulite-facies metapelites (residual after granite melt extraction) have high densities of $3 \cdot 14-3 \cdot 22 \mathrm{~g} / \mathrm{cm}^{3}$. In the case of completely anhydrous magmas only liquids produced by fractional crystallization at high pressure, exceeding $0.7 \mathrm{GPa}$ (i.e. in magma 


\section{\begin{tabular}{l|l|l|l} 
JOURNAL OF PETROLOGY & VOLUME 48 & NUMBER 1 & JANUARY 2007
\end{tabular}}
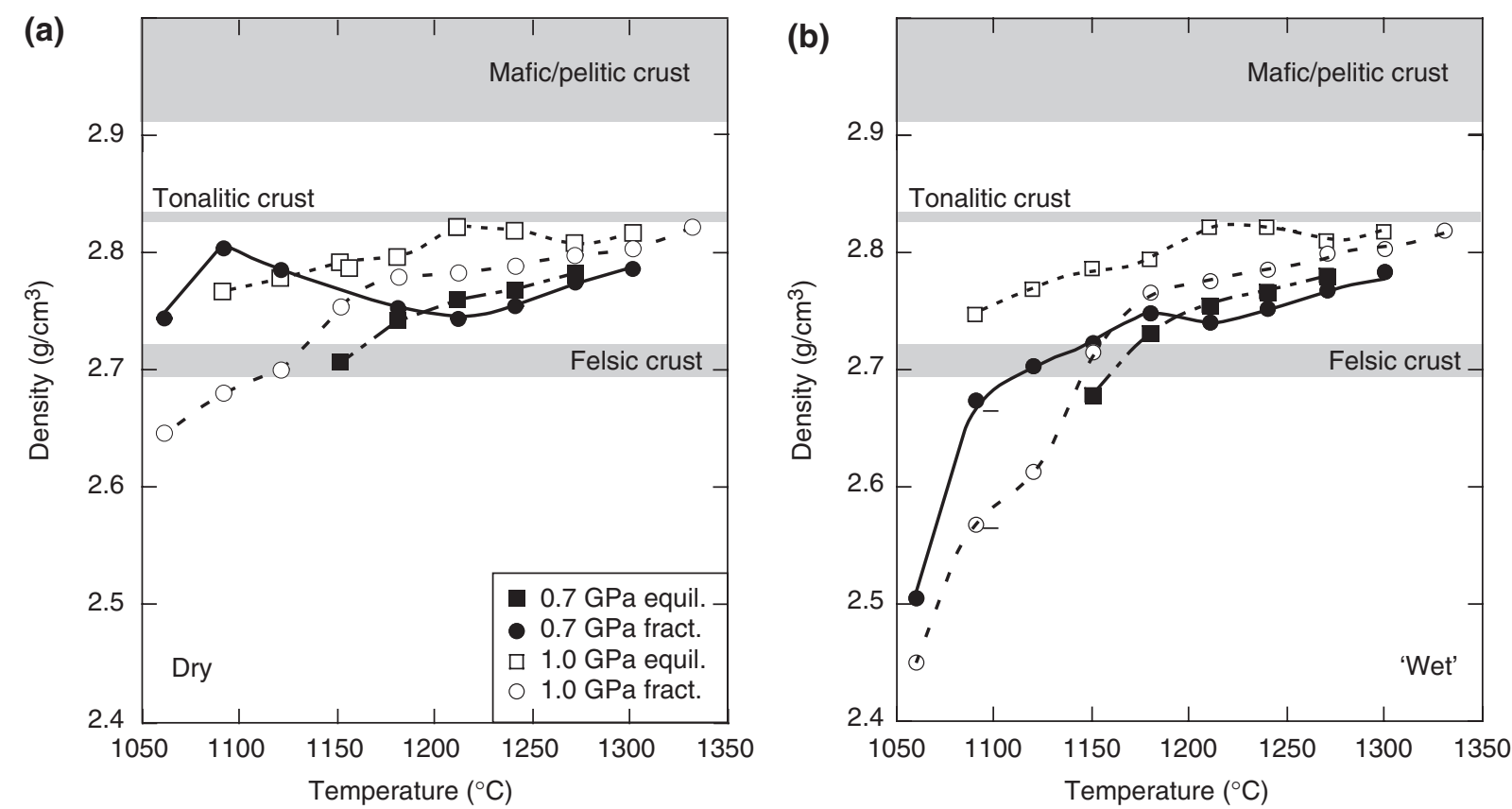

Fig. 12. Variation of calculated densities $\left(\mathrm{g} / \mathrm{cm}^{3}\right)$ of experimental liquids as a function of temperature $\left({ }^{\circ} \mathrm{C}\right)$. (a) Densities of anhydrous liquids from equilibrium and fractional crystallization experiments at $0.7 \mathrm{GPa}$ (this study) and 1.0 GPa (Villiger et al., 2004) calculated with the method of Lange \& Carmichael (1987) and Lange (1994). Partial molar volumes of the liquid oxide components have been calculated at the experimental temperatures and pressures. (b) Calculated densities of hydrous experimental liquids assuming an initial $\mathrm{H}_{2} \mathrm{O}$ content of the primary liquids (HK\#19, 19.1 or 19.2; see Table 1) of $0.1 \mathrm{wt} \%(1000 \mathrm{ppm})$. Water is assumed to behave as a perfectly incompatible element over the entire range of temperature investigated. Results of density calculations and accumulated $\mathrm{H}_{2} \mathrm{O}$ contents are given in Table 5. Densities of typical lower to middle crustal rocks are given for comparison and indicated by grey bars. For felsic and intermediate crustal rocks, average modal granite, granodiorite and tonalite compositions were taken from the Adamello batholith (Bianchi et al., 1970) and for mafic and pelitic crustal rocks modal abundances for hornblende and pyroxene gabbros and granulites and garnet-feldspar-biotite-sillimanite metapelites were taken from the Ivrea Zone (Schmid \& Wood, 1976). Densities were calculated at conditions of $0.7 \mathrm{GPa}, 650^{\circ} \mathrm{C}$ and $1.0 \mathrm{GPa}, 800^{\circ} \mathrm{C}$ using the algorithm of Hacker \& Abers (2004).

reservoirs located at depths greater than $\sim 25 \mathrm{~km}$ ), reach densities low enough to ascend to shallow levels. Low-temperature residual liquids representing rhyodacitic to rhyolitic compositions attain densities of less than $\sim 2.7 \mathrm{~g} / \mathrm{cm}^{3}$, which are typical for amphibolite-facies felsic compositions forming the middle and upper crust. Therefore, under completely dry conditions, magmas are able to ascend into and through the granulite-facies mafic to pelitic lower crust, but only differentiation within the lower part of the crust can provide liquids that can ascend to shallower levels of the crust to form granodioritic to granitic plutonic and/or rhyodacitic to dacitic sub-volcanic to volcanic complexes. Similar conclusions were reached by Herzberg et al. (1983) basing on theoretical considerations of relative magma and crustal rock densities. The fractionation experiments at $0.7 \mathrm{GPa}$ show the characteristic density distribution of typical tholeitic magmas (e.g. Sparks et al., 1980; Stolper \& Walker, 1980) with a trough in the middle range and an increase to Fe-rich liquids prior to the crystallization of $\mathrm{Fe}$-Ti-oxide that decreases the density of highly differentiated granitic liquids in the last differentiation step performed in this experimental study.
Provided that the addition of small amounts of $\mathrm{H}_{2} \mathrm{O}$ $(0.1 \mathrm{wt} \%)$ to the primary liquid does not fundamentally alter the differentiation path until about 1 wt $\%$ of $\mathrm{H}_{2} \mathrm{O}$ is reached in the liquid phase, all experiments, except the lowest three differentiation steps at 0.7 and $1.0 \mathrm{GPa}\left(1060-1120^{\circ} \mathrm{C}\right)$, should not be dramatically affected by this assumption. Figure $12 \mathrm{~b}$ shows that the addition of small amounts of $\mathrm{H}_{2} \mathrm{O}$ to the primary liquid mainly lowers the density (and the viscosity, not shown) of the liquids formed in the latest differentiation steps. This leads to the formation of 'low-density' liquids in fractionated tholeiitic basalts at both 0.7 and $1.0 \mathrm{GPa}$ as a result of the large amount of $\mathrm{H}_{2} \mathrm{O}(>3.0 \mathrm{wt} \%)$ in the highly differentiated liquids, reflecting the profound effects of $\mathrm{H}_{2} \mathrm{O}$ on the density of silicate liquids (Burnham, 1971). Similar to the observations of Grove \& Baker (1983), the accumulation of $\mathrm{H}_{2} \mathrm{O}$ in the liquid with progressive differentiation compensates the $\mathrm{Fe}$ enrichment effect of increasing density prior to $\mathrm{Fe}-\mathrm{Ti}$ oxide precipitation in the fractional crystallization experiments at $0.7 \mathrm{GPa}$. Fractional crystallization results in highly differentiated liquids representing small melt fractions compared with the initial liquid mass; these liquids 
Table 5: Calculated densities of liquid compositions for fractional and equilibrium crystallization experiments at $0.7 \mathrm{GPa}$ (this study) and 1.0 GPa (Villiger et al., 2004)

\begin{tabular}{|c|c|c|c|c|c|c|}
\hline Run no. & $P(\mathrm{GPa})$ & $T\left({ }^{\circ} \mathrm{C}\right)$ & $\mathrm{MF}_{\mathrm{acc}}$ & $\begin{array}{l}\mathrm{H}_{2} \mathrm{O}_{\text {theor. }} \\
\text { (wt \%) }\end{array}$ & $\begin{array}{l}\rho_{\text {dry }} \\
\left(\mathrm{g} / \mathrm{cm}^{3}\right)\end{array}$ & $\begin{array}{l}\rho_{\text {wet }} \\
\left(\mathrm{g} / \mathrm{cm}^{3}\right)\end{array}$ \\
\hline \multicolumn{7}{|c|}{ Fractional crystallization at $0.7 \mathrm{Gpa}$} \\
\hline HK19.2 & 0.7 & 1300 & 1.000 & $0 \cdot 10$ & $2 \cdot 78$ & $2 \cdot 78$ \\
\hline SV76 & 0.7 & 1270 & 0.940 & 0.11 & 2.77 & 2.77 \\
\hline SV96 & 0.7 & 1240 & 0.827 & 0.12 & 2.75 & 2.75 \\
\hline SV97 & 0.7 & 1210 & 0.578 & 0.17 & $2 \cdot 74$ & 2.74 \\
\hline SV99 & 0.7 & 1180 & $0 \cdot 395$ & 0.25 & 2.75 & 2.75 \\
\hline SV101 & 0.7 & 1150 & 0.156 & 0.64 & $2 \cdot 75$ & $2 \cdot 72$ \\
\hline SV103 & 0.7 & 1120 & 0.093 & $1 \cdot 08$ & $2 \cdot 78$ & $2 \cdot 70$ \\
\hline SV104 & 0.7 & 1090 & $0 \cdot 060$ & 1.66 & $2 \cdot 80$ & $2 \cdot 67$ \\
\hline SV107 & 0.7 & 1060 & 0.032 & $3 \cdot 14$ & 2.74 & 2.51 \\
\hline \multicolumn{7}{|c|}{ Equilibrium crystallization at $0.7 \mathrm{GPa}$} \\
\hline HK\#19.1 & 0.7 & 1270 & 1.000 & $0 \cdot 10$ & $2 \cdot 78$ & $2 \cdot 78$ \\
\hline SV75 & 0.7 & 1240 & 0.957 & $0 \cdot 10$ & 2.76 & 2.77 \\
\hline SV89 & 0.7 & 1210 & 0.715 & 0.14 & 2.76 & 2.75 \\
\hline SV90 & 0.7 & 1180 & 0.458 & 0.22 & $2 \cdot 74$ & $2 \cdot 73$ \\
\hline SV79 & 0.7 & 1150 & 0.239 & 0.42 & $2 \cdot 70$ & $2 \cdot 68$ \\
\hline \multicolumn{7}{|c|}{ Fractional crystallization at $1.0 \mathrm{GPa}$} \\
\hline SV46 & $1 \cdot 0$ & 1330 & $1 \cdot 000$ & 0.10 & $2 \cdot 82$ & $2 \cdot 82$ \\
\hline SV44 & 1.0 & 1300 & 0.981 & 0.10 & 2.80 & 2.80 \\
\hline SV49 & 1.0 & 1270 & 0.884 & 0.11 & 2.79 & $2 \cdot 80$ \\
\hline SV53 & 1.0 & 1240 & 0.664 & 0.15 & 2.78 & 2.79 \\
\hline SV54 & 1.0 & 1210 & 0.453 & 0.22 & 2.78 & $2 \cdot 78$ \\
\hline SV57 & 1.0 & 1180 & 0.365 & 0.27 & $2 \cdot 78$ & 2.77 \\
\hline SV58 & 1.0 & 1150 & 0.175 & 0.57 & 2.75 & $2 \cdot 72$ \\
\hline SV61 & 1.0 & 1120 & 0.087 & 1.15 & $2 \cdot 70$ & $2 \cdot 61$ \\
\hline SV63 & 1.0 & 1090 & 0.068 & 1.47 & $2 \cdot 68$ & 2.57 \\
\hline SV64 & 1.0 & 1060 & 0.037 & 2.67 & 2.64 & 2.45 \\
\hline \multicolumn{7}{|c|}{ Equilibrium crystallization at $1.0 \mathrm{GPa}$} \\
\hline SV12 & $1 \cdot 0$ & 1300 & $1 \cdot 000$ & $0 \cdot 10$ & $2 \cdot 81$ & $2 \cdot 82$ \\
\hline SV11 & $1 \cdot 0$ & 1270 & 0.975 & $0 \cdot 10$ & $2 \cdot 80$ & $2 \cdot 81$ \\
\hline SV13 & $1 \cdot 0$ & 1240 & 0.941 & 0.11 & $2 \cdot 82$ & $2 \cdot 82$ \\
\hline SV15 & $1 \cdot 0$ & 1210 & 0.726 & 0.14 & $2 \cdot 82$ & $2 \cdot 82$ \\
\hline SV27 & $1 \cdot 0$ & 1180 & 0.585 & $0 \cdot 17$ & 2.79 & 2.79 \\
\hline SV28 & $1 \cdot 0$ & 1150 & 0.527 & $0 \cdot 19$ & 2.79 & 2.79 \\
\hline SV25 & $1 \cdot 0$ & 1120 & 0.428 & 0.23 & $2 \cdot 78$ & 2.77 \\
\hline SV24 & $1 \cdot 0$ & 1090 & 0.311 & 0.32 & $2 \cdot 76$ & 2.75 \\
\hline
\end{tabular}

Densities were calculated following the method of Lange \& Carmichael (1987) and Lange (1994) for anhydrous ( $\left.\rho_{\text {dry }}\right)$ conditions and with theoretical $\mathrm{H}_{2} \mathrm{O}$ contents $\left(\rho_{\text {wet }}\right)$ starting with $0.1 \mathrm{wt} \%$ for the primary liquid (HK19.1, 19.2). Water contents have been calculated treating $\mathrm{H}_{2} \mathrm{O}$ as a totally incompatible element using the accumulated experimental melt fractions $\left(\mathrm{MF}_{\mathrm{acc}}\right)$. have low densities (and relatively low viscosities) that allow extraction from their solid residues and emplacement at shallow crustal levels, where they form either granitoid batholiths or large, ignimbrite-dominated volcanic complexes, both typical of magmatism associated with extensional tectonic settings, such as the Basin an Range Province of the Western USA or the Ivrea-Verbano-Serie dei Laghi complex in the Southern Alps of Northern Italy, where an entire cross-section from deep crustal (35 km depth) ultramafic-mafic cumulates to shallow-level $(5-10 \mathrm{~km}$ depth) granitic intrusive rocks is exposed.

\section{ACKNOWLEDGEMENTS}

This work was supported by the Swiss National Science Foundation (SNF grants 2000-61894.00/1 and 20020-105356). We would like to acknowledge the thorough and constructive reviews provided by Maik Pertermann, Claude Herzberg and David Draper. Special thanks go to Timothy L. Grove and Alan B. Thompson for extensive discussions and comments on a draft version of this contribution, and to Eric Reusser for assistance with microprobe analysis and numerical modeling.

\section{REFERENGES}

Akella, J. \& Boyd, F. R. (1972). Partitioning of Ti and Al between pyroxenes, garnets, and oxides. Carnegie Institution of Washington Yearbook 71, 378-384.

Asimow, P. D. \& Ghiorso, M. S. (1998). Algorithmic modifications extending MELTS to calculate subsolidus phase relations. American Mineralogist 83, 1127-1131.

Baker, D. R. \& Eggler, D. H. (1983). Fractionation paths of Atka (Aleutians) high alumina basalts: constraints from phase relations. Journal of Volcanology and Geothermal Research 18, 387-404.

Baker, D. R. \& Eggler, D. H. (1987). Compositions of anhydrous and hydrous melts coexisting with plagioclase, augite, and olivine or low-Ca pyroxene from $1 \mathrm{~atm}$ to $8 \mathrm{kbar}$ : application to Aleutian volcanic center of Atka. American Mineralogist 72, 12-28.

Baker, M. B., Grove, T. L. \& Price, R. (1994). Primitive basalts and andesites from the Mt. Shasta region, N. California: products of varying melt fractions and water contents. Contributions to Mineralogy and Petrology 118, 111-129.

Bartels, K. S., Kinzler, R. J. \& Grove, T. L. (1991). High-pressure phase relations of primitive high-alumina basalts from Medicine Lake volcano, northern California. Contributions to Mineralogy and Petrology 108, 253-270.

Bender, J. F., Hodges, F. N. \& Bence, A. E. (1978). Petrogenesis of basalts from the project FAMOUS area: experimental study from 0 to 15 kbar. Earth and Planetary Science Letters 41, 277-302.

Bergantz, G. W. (1989). Underplating and partial melting; implications for melt generation and extraction. Science 245, 1093-1095.

Berndt, J., Koepke, J. \& Holtz, F. (2005). An experimental investigation of the influence of water and oxygen fugacity on differentiation of MORB at $200 \mathrm{MPa}$. Fournal of Petrology 46, 135-167.

Bianchi, A., Callegari, E. \& Jobstraibizer, P. G. (1970). I tipi petrografici fondamentali del Plutone dell'Adamello. Memorie degli Istituti di Geologia e Mineralogia dell'Universita di Padova 27, 1-146. 


\section{\begin{tabular}{l|l|l|l} 
JOURNAL OF PETROLOGY & VOLUME 48 & NUMBER 1 & JANUARY 2007
\end{tabular}}

Blundy, J. D., Falloon, T. J., Wood, B. J. \& Dalton, J. A. (1995). Sodium partitioning between clinopyroxene and silicate melts. Fournal of Geophysical Research 100, 501-515.

Bohlen, S. R., Essene, E. J. \& Boettcher, A. J. (1980). Reinvestigations and applications of olivine-quartz-orthopyroxene barometry. Earth and Planetary Science Letters 47, 1-10.

Bose, K. \& Ganguly, J. (1995). Quartz-coesite revisited: reversed experimental determinations at $500-1000^{\circ} \mathrm{C}$ and retrieved thermochemical properties. American Mineralogist 80, 231-238.

Boyd, F. R. \& England, J. L. (1960). Apparatus for phaseequilibrium measurements at pressures up to 50 kilobars and temperatures up to $1750^{\circ} \mathrm{C}$. Fournal of Geophysical Research $\mathbf{6 5}$, $741-748$.

Brey, G. P., Weber, R. \& Nickel, K. G. (1990). Calibration of belt apparatus to $1800^{\circ} \mathrm{C}$ and $6 \mathrm{GPa}$. Journal of Geophysical Research 95, 15603-15610.

Burnham, C. W. (1971). Water and magmas: a mixing model. Geochimica et Cosmochimica Acta 39, 1077-1084.

Clark, S. P. (1959). Effect of pressure on the melting points of eight alkali halides. Fournal of Chemical Physics 31, 1526-1531.

Cox, K. G. (1980). A model for flood basalt volcanism. Fournal of Petrology 21, 629-650.

Demarchi, G., Quick, J. E., Sinigoi, S. \& Mayer, A. (1998). Pressure gradient and original orientation of a lower-crustal intrusion in the Ivrea-Verbano Zone, Northern Italy. Fournal of Geology 106, 609-622.

Eggins, S. M. (1992). Petrogenesis of Hawaiian tholeiites: 1, phase equilibria constraints. Contributions to Mineralogy and Petrology 110, 387-397.

Elthon, D. \& Scarfe, C. M. (1984). High-pressure phase equilibria of a high-magnesia basalt and the genesis of primary oceanic basalts. American Mineralogist 69, 1-15.

Forsythe, L. M., Nielsen, R. L. \& Fisk, M. R. (1994). High-fieldstrength element partitioning between pyroxene and basaltic to dacitic magmas. Chemical Geology 117, 107-125.

Fram, M. S. \& Longhi, J. (1992). Phase equilibria of dikes associated with Proterozoic anorthosite complexes. American Mineralogist 77, 605-616.

Frost, D. J. \& Wood, B. J. (1995). Experimental measurements of the graphite $\mathrm{C}-\mathrm{O}$ equilibrium and $\mathrm{CO}_{2}$ fugacities at high temperatures and pressure. Contributions to Mineralogy and Petrology 121, 303-308.

Gaetani, G. A. \& Grove, T. L. (1998). The influence of water on melting of mantle peridotite. Contributions to Mineralogy and Petrology 131, 323-346.

Ghiorso, M. S. \& Carmichael, I. S. E. (1985). Chemical mass transfer in magmatic processes. II. Applications in equilibrium crystallization, fractionation and assimilation. Contributions to Mineralogy and Petrology 90, 121-141.

Ghiorso, M. S. \& Sack, R. O. (1995). Chemical mass transfer in magmatic processes IV. A revised and internally consistent thermodynamic model for the interpretation and extrapolation of liquid-solid equilibria in magmatic systems at elevated temperatures and pressures. Contributions to Mineralogy and Petrology 119, 197-212.

Ghiorso, M. S., Hirschmann, M. M., Reiners, P. W. \& Kress, V. C. I. (2002). The pMELTS: a revision of MELTS aimed at improving calculation of phase relations and major element partitioning involved in partial melting of the mantle at pressures up to $3 \mathrm{GPa}$. Geochemistry, Geophysics, Geosystems 3, doi:10.1029/ 2001GC000217.

Green, D. H. \& Ringwood, A. E. (1967). The genesis of basaltic magmas. Contributions to Mineralogy and Petrology 15, 103-190.
Grove, T. L. \& Baker, M. B. (1983). Effects of melt density on magma mixing in calc-alkaline series lavas. Nature 305, 416-418.

Grove, T. L. \& Baker, M. B. (1984). Phase equilibrium controls on the tholeiitic versus calc-alkaline differentiation trends. Fournal of Geophysical Research 89, 3253-3274.

Grove, T. L. \& Bryan, W. B. (1983). Fractionation of pyroxene-phyric MORB at low pressure: an experimental study. Contributions to Mineralogy and Petrology 84, 293-309.

Grove, T. L., Kinzler, R. J. \& Bryan, W. B. (1990). Natural and experimental phase relations of lavas from Serocki Volcano. In: Detrick, R., Honnorez, J., Brian, W. B. et al. (eds) Proceedings of the Ocean Drilling Program, Scientific Results, 106. College Station, TX: Ocean Drilling Program, pp. 9-17.

Grove, T. L., Kinzler, R. J. \& Bryan, W. B. (1992). Fractionation of mid-ocean ridge basalt (MORB). In: Phipps Morgan, J., Blackman, D. K. \& Sinton, J. M. (eds) Mantle Flow and Melt Generation at Mid-ocean Ridges. Geophysical Monograph, American Geophysical Union 71, 281-310.

Gust, D. A. \& Perfit, M. R. (1987). Phase relations of a high-Mg basalt from the Aleutian Island Arc: implications for primary island arc basalts and high Al basalts. Contributions to Mineralogy and Petrology 97, 7-18.

Hacker, B. R. \& Abers, G. A. (2004). Subduction factory 3: an Excel worksheet and macro for calculating the densities, seismic wave speeds, and $\mathrm{H}_{2} \mathrm{O}$ contents of minerals and rocks at pressure and temperature. Geochemistry, Geophysics, Geosystems 5, doi: 10.1029/2003GC000614.

Hermann, J., Müntener, O. \& Günther, D. (2001). Differentiation of mafic magma in a continental crust-to-mantle transition zone. Journal of Petrology 42, 189-206.

Herzberg, C. (2004). Partial crystallization of mid-ocean ridge basalts in the crust and mantle. Fournal of Petrology 45, 2389-2405.

Herzberg, C. T., Fyfe, W. S. \& Carr, M. J. (1983). Density constraints on the formation of the continental Moho and crust. Contributions to Mineralogy and Petrology 84, 1-5.

Hill, E., Wood, B. J. \& Blundy, J. D. (2000). The effect of Ca-Tschermaks component on trace element partitioning between clinopyroxene and silicate melt. Lithos 53, 203-215.

Hirose, K. \& Kushiro, I. (1993). Partial melting of dry peridotites at high pressures: determination of compositions of melts segregated from peridotite using aggregates of diamond. Earth and Planetary Science Letters 114, 477-489.

Holbrook, W. S. \& Kelemen, P. (1993). Large igneous province on the US Atlantic margin and implications for magmatism during continental break up. Nature 364, 433-436.

Johnson, K. T. M. (1998). Experimental determination of partitioning coefficients for rare earth and high-field-strength elements between clinopyroxene, garnet, and basaltic melt at high pressures. Contributions to Mineralogy and Petrology 133, 60-68.

Kägi, R. (2000). The liquid line of descent of hydrous, primary, calc-alkaline magmas and elevated pressure. An experimental approach. PhD Dissertation, ETH Zurich, 115 pp.

Kelemen, P. \& Aharonov, E. (1998). Periodic formation of magma fractures and generation of layered gabbros in the lower crust beneath oceanic spreading ridges. In: Buck, W. R., Delaney, P. T., Karson, J. A. \& Lagabrielle, Y. (eds) Faulting and Magmatism at Midocean Ridges. Geophysical Monograph, American Geophysical Union 106, 267-289.

Kelemen, P., Johnson, K. T. M., Kinzler, R. J. \& Irving, A. J. (1990). High-field-strength element depletions in arc basalts due to mantle-magma interaction. Nature 345, 521-524. 
Kinzler, R. J. \& Grove, T. L. (1992). Primary magmas of mid-ocean ridge basalts 1. Experiments and methods. Fournal of Geophysical Research 97, 6885-6906.

Kress, V. C. \& Carmichael, I. S. E. (1991). The compressibility of silicate liquids containing $\mathrm{Fe}_{2} \mathrm{O}_{3}$ and the effect of composition, temperature, oxygen fugacity and pressure on their redox state. Contributions to Mineralogy and Petrology 108, 82-92.

Kushiro, I. \& Mysen, B. O. (2002). A possible effect of melt structure on the $\mathrm{Mg}-\mathrm{Fe}^{2+}$ partitioning between olivine and melt. Geochimica et Cosmochimica Acta 66, 2267-2272.

Lange, R.A. (1994). The effect of $\mathrm{H}_{2} \mathrm{O}, \mathrm{CO}_{2}$ and $\mathrm{F}$ on the density and viscosity of silicate melts. In: Carroll, M. R. \& Holloway, J. R. (eds) Volatiles in Magmas. Mineralogical Society of America, Reviewes in Mineralogy 30, 331-369.

Lange, R.A. \& Carmichael, I.S.E. (1987). Densities of $\mathrm{Na}_{2} \mathrm{O}-\mathrm{K}_{2} \mathrm{O}-$ $\mathrm{CaO}-\mathrm{MgO}-\mathrm{FeO}-\mathrm{Fe}_{2} \mathrm{O}_{3}-\mathrm{Al}_{2} \mathrm{O}_{3}-\mathrm{TiO}_{2}-\mathrm{SiO}_{2}$ liquids: new measurements and derived partial molar properties. Geochimica et Cosmochimica Acta 51, 2931-2946.

Lightfoot, P. C., Hawkesworth, C. J., Devey, C. W., Rogers, N. W. \& Van Calsteren, P. W. C. (1990). Source and differentiation of Deccan Trap lavas; implications of geochemical and mineral chemical variations. Fournal of Petrology 31, 1165-1200.

Lundstrom, C. C., Shaw, H. F., Ryerson, F. J., Williams, Q. \& Gill, J. (1998). Crystal chemical control of clinopyroxene-melt partitioning in the $\mathrm{Di}-\mathrm{Ab}-\mathrm{An}$ system: implications for elemental fractionations in the depleted mantle. Geochimica et Cosmochimica Acta 62, 2849-2862.

Michael, P. J. \& Cornell, W. C. (1998). Influence of spreading rate and magma supply on crystallization and assimilation beneath mid-ocean ridges: evidence from chlorine and major element chemistry of mid-ocean ridge basalts. Fournal of Geophysical Research 103, 18325-18356.

Muan, A. (1958). Phase equilibria at high temperatures in oxide systems involving changes in oxidation states. American fournal of Science 256, 171-207.

Müntener, O., Hermann, J. \& Trommsdorff, V. (2000). Cooling history and exhumation of lower-crustal granulite and upper mantle (Malenco, Eastern Central Alps). Fournal of Petrology 41, 175-200.

Mutter, J. C., Talwani, M. \& Stoffa, P. L. (1984). Evidence for a thick oceanic crust adjacent to the Norwegian margin. Fournal of Geophysical Research 89, 483-502.

Onuma, K. \& Yagi, K. (1971). The join $\mathrm{CaMgSi}_{2} \mathrm{O}_{6}-\mathrm{Ca}_{2} \mathrm{MgSi}_{2} \mathrm{O}_{7}-$ $\mathrm{CaTiAl}_{2} \mathrm{O}_{6}$ in the system $\mathrm{CaO}-\mathrm{MgO}-\mathrm{Al}_{2} \mathrm{O}_{3}-\mathrm{TiO}_{2}-\mathrm{SiO}_{2}$ and its bearing on titan pyroxenes. Mineralogical Magazine and fournal of the Mineralogical Society 38, 471-480.

Panjasawatwong, Y., Danyushevsky, L. V., Crawford, A. J. \& Harris, K. L. (1995). An experimental study of the effects of melt composition on plagioclase-melt equilibria at 5 and $10 \mathrm{kbar}$ : implications for the origin of magmatic high-An plagioclase. Contributions to Mineralogy and Petrology 118, 320-432.

Pertermann, M. \& Hirschmann, M. M. (2003). Anhydrous partial melting experiments on MORB-like eclogite: phase relations, phase compositions and mineral-melt partitioning of major elements at 2-3 GPa. Fournal of Petrology 44, 2173-2201.

Putirka, K., Johnson, M., Kinzler, R. J., Longhi, J. \& Walker, D. (1996). Thermobarometry of mafic igneous rocks based on clinopyroxene-liquid equilibria, 0-30 kbar. Contributions to Mineralogy and Petrology 123, 92-108.

Rivalenti, G., Garuti, G. \& Rossi, A. (1975). The origin of the Ivrea-Verbano basic formation (western Italian Alps); whole rock geochemistry. Bollettino della Società Geologica Italiana 94, 1149-1186.
Rivalenti, G., Rossi, A., Franca, S. \& Sinigoi, S. (1984). The layered series of the Ivrea-Verbano igneous complex, Western Alps, Italy. Tschermaks Mineralogische und Petrographische Mitteilungen 33, 77-99.

Roedder, P. L. \& Emslie, R. F. (1970). Olivine-liquid equilibrium. Contributions to Mineralogy and Petrology 29, 275-289.

Sano, T., Fujii, T., Deshnukh, S. S., Fukuoka, T. \& Aramaki, S. (2001). Differentiation processes of Deccan Trap basalts: contribution from geochemistry and experimental petrology. Fournal of Petrology 42, 2175-2195.

Schmid, R. \& Wood, B. J. (1976). Phase relationships in granulitic metapelites from the Ivrea-Verbano Zone (Northern Italy). Contributions to Mineralogy and Petrology 54, 255-279.

Sisson, T. W. \& Grove, T. L. (1993). Experimental investigations of the role of $\mathrm{H}_{2} \mathrm{O}$ in calc-alkaline differentiation and subduction zone magmatism. Contributions to Mineralogy and Petrology 113, 143-166.

Sparks, R. S. I., Meyer, P. \& Sigurdsson, H. (1980). Density variation amongst mid-ocean ridge basalts: implications for magma mixing and the scarcity of primitive lavas. Earth and Planetary Science Letters 46, 419-430.

Stolper, E. \& Walker, D. (1980). Melt density and the average composition of basalt. Contributions to Mineralogy and Petrology 74, 7-12.

Thompson, R. N. (1974). Some high-pressure pyroxenes. Mineralogical Magazine 39, 768-787.

Thompson, R. N., Gibson, I. L., Marriner, G. F., Mattey, D. P. \& Morrison, M. A. (1980). Trace-element evidence of multistage mantle fusion and polybaric fractional crystallisation in the Paleocene lavas of Skye, NW Scotland. Fournal of Petrology 21, 265-293.

Thy, P., Lesher, C. E. \& Mayfield, J. D. (1999). Low-pressure melting studies of basalt and basaltic andesite from the southeast Greenland continental margin and the origin of dacites at site 917. In: Larsen, H. C., Duncan, R. A., Allan, J. F., Brooks, K. et al. (eds) Proceedings of the Ocean Drilling Program, Scientific Results, 163. College Station, TX: Ocean Drilling Program, pp. 95-112.

Toplis, M. J., Libourel, G. \& Carroll, M. R. (1994). The role of phosphorus in the crystallisation processes of basalt: an experimental study. Geochimica et Cosmochimica Acta 58, 797-810.

Tormey, D. R., Grove, T. L. \& Bryan, W. B. (1987). Experimental petrology of normal MORB near the Kane Fracture Zone: $22-25^{\circ} \mathrm{N}$, mid-Atlantic ridge. Contributions to Mineralogy and Petrology 96, 121-139.

Ulmer, P. (1989). The dependence of the $\mathrm{Fe}^{2+}-\mathrm{Mg}$ cation-partitioning between olivine and basaltic liquid on pressure, temperature and composition. An experimental study to 30 kbars. Contributions to Mineralogy and Petrology 101, 261-273.

Ulmer, P. \& Luth, R. W. (1991). The graphite- $\mathrm{COH}$ fluid equilibrium in $P, T, f \mathrm{O}_{2}$ space. An experimental determination to $30 \mathrm{kbar}$ and $1600^{\circ}$ C. Contributions to Mineralogy and Petrology 106, 265-272.

Verhoogen, J. (1962). Distribution of titanium between silicates and oxides in igneous rocks. American fournal of Science 260, 211-220.

Villiger, S., Ulmer, P., Müntener, O. \& Thompson, A. B. (2004). The liquid line of descent of anhydrous, mantle-derived, tholeiitic liquids by fractional and equilibrium crystallization - an experimental study at 1.0 GPa. Fournal of Petrology 45, 2369-2388.

Villiger, S., Müntener, O. \& Ulmer, P. (2006). Crystallization pressures of mid-ocean ridge basalts derived from major element variations of glasses from equilibrium and fractional crystallization experiments. Fournal of Geophysical Research, Solid Earth, doi: 10.1029/ 2006JB004342 (in press). 
Wood, B. J. \& Trigila, R. (2001). Experimental determination of aluminous clinopyroxene-melt partition coefficients for potassic liquids, with application to the evolution of the Roman province potassic magmas. Chemical Geology 172, 213-223.
Yang, H. J., Kinzler, R. J. \& Grove, T. L. (1996). Experiments and models of anhydrous, basaltic olivine-plagioclase-augite saturated melts from $0 \cdot 001$ to 10 kbar. Contributions to Mineralogy and Petrology 124, 1-18. 